\title{
Influence of Sea Surface Temperature on a Mesoscale Convective System Producing Extreme Rainfall over the Yellow Sea
}

\author{
YunheE KAng, ${ }^{\mathrm{a}}$ Jong-HoOn JeOng, ${ }^{\mathrm{b}}$ AND Dong-In LeE ${ }^{\mathrm{a}}$ \\ ${ }^{a}$ Department of Environmental Atmospheric Sciences, Pukyong National University, Busan, South Korea \\ ${ }^{\mathrm{b}}$ Atmospheric Science and Global Change Division, Pacific Northwest National Laboratory, Richland, Washington
}

(Manuscript received 20 October 2020, in final form 11 May 2021)

\begin{abstract}
An extreme-rainfall-producing linear mesoscale convective system (MCS) occurred over the Yellow Sea, Korea, on 13 August 2012, producing $430 \mathrm{~mm}$ of rainfall in less than $12 \mathrm{~h}$, causing devastating flash floods and landslides. To understand the causative processes underlying this event, we examined the linear MCS's formation and development mechanisms using observations and cloud-resolving models. The organized linear MCS produced extreme rainfall at Gunsan in a favorable large-scale environment. The synoptic environment showed the stationary surface front elongating from China to Korea; a southwesterly low-level jet transported the warm, moist air from low latitudes toward the front. In the upper-level synoptic environment, the trough and entrance regions of the upper-level jet were north of the heavy rainfall, promoting the development of convection. The extreme rainfall over the Gunsan area resulted from the backbuilding mode of the MCS, in which new convective cells continued to pass over the same area while the entire convective system was nearly stationary. The sea surface temperature (SST) during the extreme rainfall events was abnormally $1^{\circ} \mathrm{C}$ higher than the 30-yr climatological mean, and a local warm pool $\left(>28.5^{\circ} \mathrm{C}\right)$ existed where the convective cells were continuously initiated. Cloud-resolving models simulated the low-level convergence, and the latent heat flux was large in the local warm SST field. These induced MCS formation and development, contributing to a significant rainfall increase over the Yellow Sea. The terrain's influence on the large rainfall amount in the area was also noted.
\end{abstract}

KEYWORDS: Convective storms/systems; Mesoscale systems; Sea surface temperature; Radars/Radar observations; Cloud resolving models

\section{Introduction}

Heavy rainfall during the warm season causes natural disasters such as flash floods and landslides that cause human injuries and socioeconomic damage. In particular, the most extreme rainfall events are caused by slow-moving mesoscale convective systems (MCSs; Houze 2019). MCSs are composed of a continuous precipitation region covering a horizontal scale of at least $100 \mathrm{~km}$ (Houze 2004). Warm-season quantitative precipitation forecasts (QPFs) for heavy-rainfall-producing MCSs are highly important. However, numerical models have limitations in predicting the accurate location and intensity of heavy rainfall (Fritsch and Carbone 2004; Sukovich et al. 2014; Schumacher 2017; Herman and Schumacher 2018; Tsuboki and Luo 2021) since initial convection related to heavy rainfall occurs at small spatial scales (less than $100 \mathrm{~km}$ ) and persists for relatively short periods (6 h or less) (Smith et al. 2007; Wang et al. 2017; Shimizu et al. 2019). To improve the warm-season QPFs for such heavy rainfall events, an accurate understanding of the physical processes and factors contributing to the formation, development, and maintenance of convection is essential.

Kang's current affiliation: Institute for Space-Earth Environmental Research, Nagoya University, Nagoya, Japan.

Jeong's current affiliation: Joint Institute for Regional Earth System Science and Engineering, University of California, Los Angeles, California.

Corresponding author: Dong-In Lee, leedi@pknu.ac.kr
Recently, numerous studies have documented the size, shape, and motion of MCSs that produce heavy rainfall. Doswell et al. (1996) discussed how the shape and movement of MCSs determine the rainfall amount at a specific geographic point. Heavy rainfall is more likely to occur when the rainfall intensity is higher, the duration time is longer at a fixed location, or when both factors are present. These can be summarized using a simple equation for rainfall accumulation:

$$
P=\bar{R} D
$$

where $P$ is the total precipitation, $\bar{R}$ is the average rainfall rate, and $D$ is the duration of rainfall (Doswell et al. 1996).

Based on the radar-observed reflectivity image, Parker and Johnson (2000) reported on the three linear MCS archetypes: trailing stratiform (TS), leading stratiform (LS), and parallel stratiform (PS). Subsequently, Schumacher and Johnson (2005, 2006) stated that two MCS archetypes were most frequently responsible for heavy rainfall. The trailing line-adjoining stratiform system (TL/AS) type is formed when the individual cell motion is almost parallel to the convective line. The second type is the back-building/quasi-stationary (BB) system, which involves the formation of new cells (decay) repeatedly upstream (downstream) at a geographically fixed location, resulting in the convective region of an almost quasi-stationary MCS. These MCSs continuously move over a specific location with heavy rainfall. These BB types have also been found in many studies on extreme rainfall events in East Asia (e.g., Luo et al. 2014; Luo and Chen 2015; Jeong et al. 2016b; Wang et al. 2016; Liu et al. 2018; M. Li et al. 2020; Kato 2020; Min et al. 2021). 
In these phenomena, heavy rainfall is considerably influenced by the synoptic environment and the characteristics of the underlying surface. In East Asia, synoptic heavy rainfall events mainly occur during the warm season (known as the mei-yu-baiu-changma season, May-July, e.g., Luo et al. 2016; Wu et al. 2017; Z. Li et al. 2020). During the mei-yu-baiuchangma season, warm moist air along the southwesterly low-level jets (LLJs) over the stationary front (mei-yu-baiuchangma front), leading to heavy-rain-producing MCS (e.g., Ding 2004; Du and Chen 2018, 2019a,b; Liu et al. 2020; Moroda et al. 2021). Du and Chen (2019a) demonstrated that LLJs play an important role in convection initiation through mesoscale lifting (convergence and divergence) and midlevel moistening, resulting in the formation and maintenance of heavy rainfall in coastal urban areas. In addition, heavy rainfall during the warm season is usually related to topography (e.g., Lee et al. 2012; Li et al. 2014; Xia and Zhang 2019; Ke et al. 2019), coastline (Lee et al. 2019), and urbanization (Jiang et al. 2020; Yin et al. 2020). The underlying surface (topography, coastline, urbanization) can affect the amount, distribution, and intensity of rainfall by local variations in convergence distribution and ascending airflow (Du et al. 2020; Lin et al. 2021). Wang et al. (2005), using numerical modeling, showed that the effects of topography on a convective line during the mei-yu season resulted in heavy rainfall. In an experiment with different terrain heights, when the height of the terrain was decreased, the convergence was weaker, and the rainfall distribution and intensity changed under moist, unstable environmental conditions.

Studies on heavy-rainfall-producing MCSs have mainly focused on atmospheric factors. However, because heavy rainfall can also be caused by the underlying coupled complex processes, it is important to understand not only the factors related to the atmosphere but also the air-sea interaction. Some recent studies on air-sea interactions pertaining to heavy rainfall have explained that local sea surface temperatures (SSTs) have a significant impact on the planetary boundary layer (PBL) in midlatitude heavy rainfall events (Chelton et al. 2004; Xie 2004; Small 2008; Chelton and Xie 2010; Xu et al. 2011). Chelton and Xie (2010) reviews indicate that the strong positive correlation between SSTs and surface winds on the mesoscale ocean influences the PBL. The surface wind speeds are relatively increasing (decreasing) over warm (cool) SST fields. Therefore, the increased surface wind speed over warmer SST fields enhances the low-level convergence and induces energetic evaporation. Water vapor (with a large amount of latent heat) released into the atmosphere by evaporation is mixed in the PBL and influences the rain formation process (Minobe et al. 2008; Li and Carbone 2012; Miyama et al. 2012; Sasaki et al. 2012).

Tsuguti and Kato (2014), using observation data and numerical simulation results, showed that in the case of a heavy rainfall event on Amami-Oshima Island, local warm SSTs intensified the latent heat flux associated with the air-sea interaction and contributed to the air-parcel transformation. During the Terrain-influenced Monsoon Rainfall Experiment (TiMREX), a relatively strong gradient in the SSTs was found to influence the PBL (Toy and Johnson 2014). They suggested that a strong SST gradient induced low-level convergence development and

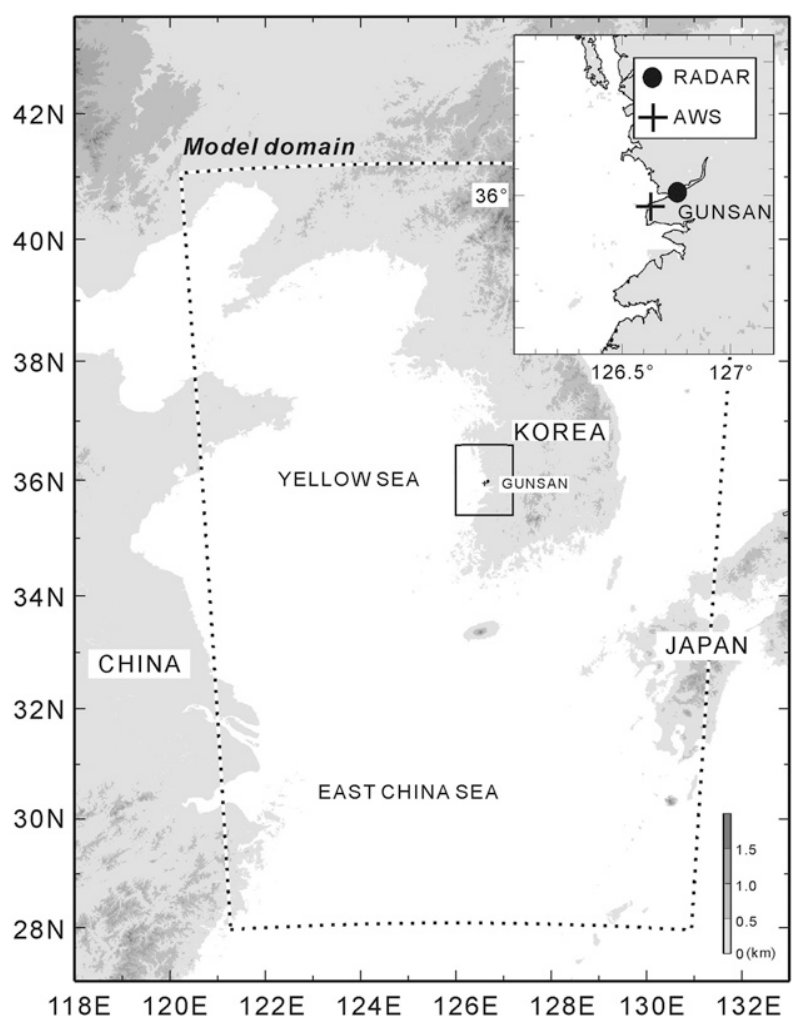

FIG. 1. Geography and topography (m, shading) of the Korean Peninsula and surrounding areas. The dotted box shows the model domain used in this study. The black solid box shows the domain of the box at the upper-right corner. Symbols indicate the positions of the AWS station operated by the KMA (marked by + ) and the KSN (GUNSAN) radar (marked by $\bullet$ ).

triggered precipitation enhancement. Sato et al. (2016) showed that high SSTs of the Kuroshio affected the increasing moisture content of the air mass in the PBL. It was identified as the cause of heavy rainfall in the baiu frontal zone over the East China Sea.

Only a few studies have examined the influence of local SSTs on convection characteristics, including heavy rainfall production in East Asia. This study focuses on the area of the Yellow Sea near Korea (see Fig. 1) and aims to understand the factors resulting in heavy-rainfall-producing MCSs and the impact of the SSTs on air-sea interaction. To investigate the MCSs' development process over the sea, a case where MCS occurred over the Yellow Sea and moved inland was selected. On 13 August 2012, an extreme rainfall event occurred along the west coast of Korea. This event is the fourth-highest rainfall record since 1968 .

The observation part of this study presents the synoptic conditions, factors contributing to MCSs, and the characteristics of the SST field over the Yellow Sea. The simulation part of this study examines the differences in the MCS development process that results in heavy rainfall with SST variations through experiments. To the best of our knowledge, this is the first report showing the impact of local SSTs on MCSproducing heavy rainfall over the Yellow Sea during the 
summer season. The remainder of this paper is organized as follows. The data and methodology are presented in section 2, and an event overview is described in section 3. Section 4 describes the model configuration, and section 5 provides the model results. Finally, section 6 provides a discussion and summary.

\section{Data and methodology}

To discuss the synoptic conditions of this event, the National Centers for Environmental Prediction-National Center for Atmospheric Research (NCEP-NCAR) global reanalysis dataset was examined four times daily $(0000,0600,1200$, and 1800 UTC) with a horizontal resolution of $2.5^{\circ} \times 2.5^{\circ}$ and 17 pressure levels (from 1000 to $10 \mathrm{hPa}$ ) were used (Kalnay et al. 1996).

Operational S-band (10-cm) Doppler radar observations of the Korea Meteorological Administration (KMA) were used to investigate the evolution and movement of MCSs from the Yellow Sea to the central part of the Korea. The radar from the Gunsan $\left(\mathrm{KSN}, 36.00^{\circ} \mathrm{N}, 126.78^{\circ} \mathrm{E}\right.$, altitude $\left.=231 \mathrm{~m}\right)$ covers a radius of $180 \mathrm{~km}$, and the volume scan consisted of 15 elevations angles $\left(0.5^{\circ}, 0.8^{\circ}, 0.9^{\circ}, 1.1^{\circ}, 1.5^{\circ}, 2.0^{\circ}, 2.6^{\circ}, 3.5^{\circ}, 4.6^{\circ}, 6.0^{\circ}\right.$, $8.0^{\circ}, 10.5^{\circ}, 13.8^{\circ}, 18.2^{\circ}$, and $\left.24.0^{\circ}\right)$. The Doppler radar data were interpolated in a Cartesian coordinate system with a $1-\mathrm{km}$ (0.25-km) horizontal (vertical) grid interval. A Cressman-type weighting function is used for interpolation (Cressman 1959). The reflectivity mosaic was obtained from an $11 \mathrm{~S}$-band Doppler radar network operated by the KMA, covering the Korean Peninsula with a $1-\mathrm{km}$ horizontal grid spacing. The reflectivity mosaic in this study was extracted at a $1.5-\mathrm{km}$ height, and quality control (QC) algorithms were applied to eliminate excessive noise in the radar measurements at lower layers. In addition, the ECMWF atmospheric hourly reanalysis (ERA5), which provides global, 1-hourly atmospheric fields at $0.25^{\circ} \times 0.25^{\circ}$ spatial resolution, was used to describe the moving linear convective system with a reflectivity mosaic (Hersbach et al. 2020).

TRMM Multisatellite Precipitation Analysis (TMPA) 3B42 rain rates (Huffman et al. 2007) at $0.25^{\circ}$ latitude every $3 \mathrm{~h}$ were employed to visualize the overall distribution of rainfall in the Yellow Sea and Kore. The surface rainfall amount received from 694 surface stations of the automatic weather system (AWS) operated by the KMA was analyzed to investigate the accumulated rainfall amount. The QC algorithms were applied by KMA, and rainfall amounts were provided every 1-min temporal resolution. To show the spatial distribution of rainfall amount over the Korea, rainfall amount data were interpolated from the observational sites within neighborhoods, and the Cressman analysis scheme was adapted (Cressman 1959). The station density can have large errors in interpolating rain because the distribution of rainfall varies depending on the complex terrain (Daly 2006; Daly et al. 2008). In Korea, the AWS station density is high (approximately 10-km horizontal resolution), but the number of AWS stations decreased as the altitude increased. Therefore, the Cressman analysis overestimates precipitation as the altitude increases (Hewitson and Crane 2005). In addition, Jeong et al. (2020) showed that overestimation of rainfall intensity occurred in complex mountainous

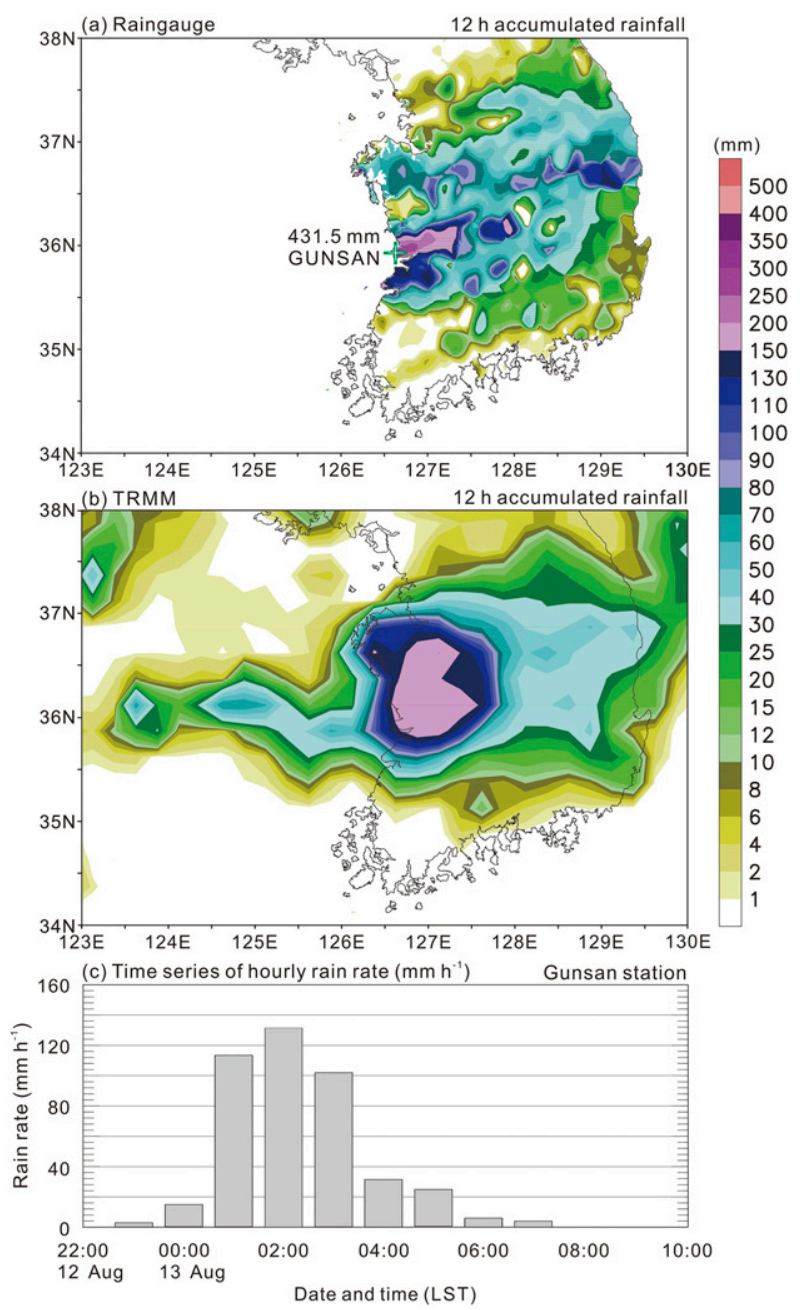

FIG. 2. The 12-h accumulated rainfall (mm, color shading) from 2100 LST 12 Aug to 0900 LST 13 Aug 2012 (a) surface automatic weather stations and (b) TRMM 3B42 data. The labeled + symbol indicates the location of the maximum rainfall amount in (a). (c) Time series of hourly rain rate $\left(\mathrm{mm} \mathrm{h}^{-1}\right)$ at Gunsan station $\left(35.95^{\circ} \mathrm{N}, 126.59^{\circ} \mathrm{E}\right)$.

regions in Korea using the parameter-elevation regression on an independent slopes model (PRISM).

The merged satellite and in situ data global daily surface temperatures (MGDSST) in operation at the Japan Meteorological Agency (JMA) are used (Sakurai et al. 2005; Kurihara et al. 2006) to analyze SST fields over the Yellow Sea. The horizontal resolution was $0.25^{\circ}$ latitude and longitude.

\section{Event overview}

\section{a. Synoptic environment}

In this section, the synoptic conditions are described by investigating the environmental conditions for extreme rainfall events. Figure 2 a shows the distribution of the 12 -h rainfall over Korea from the rain gauge network. The rainfall was eastwest-oriented, widespread, and covered the entire country. 

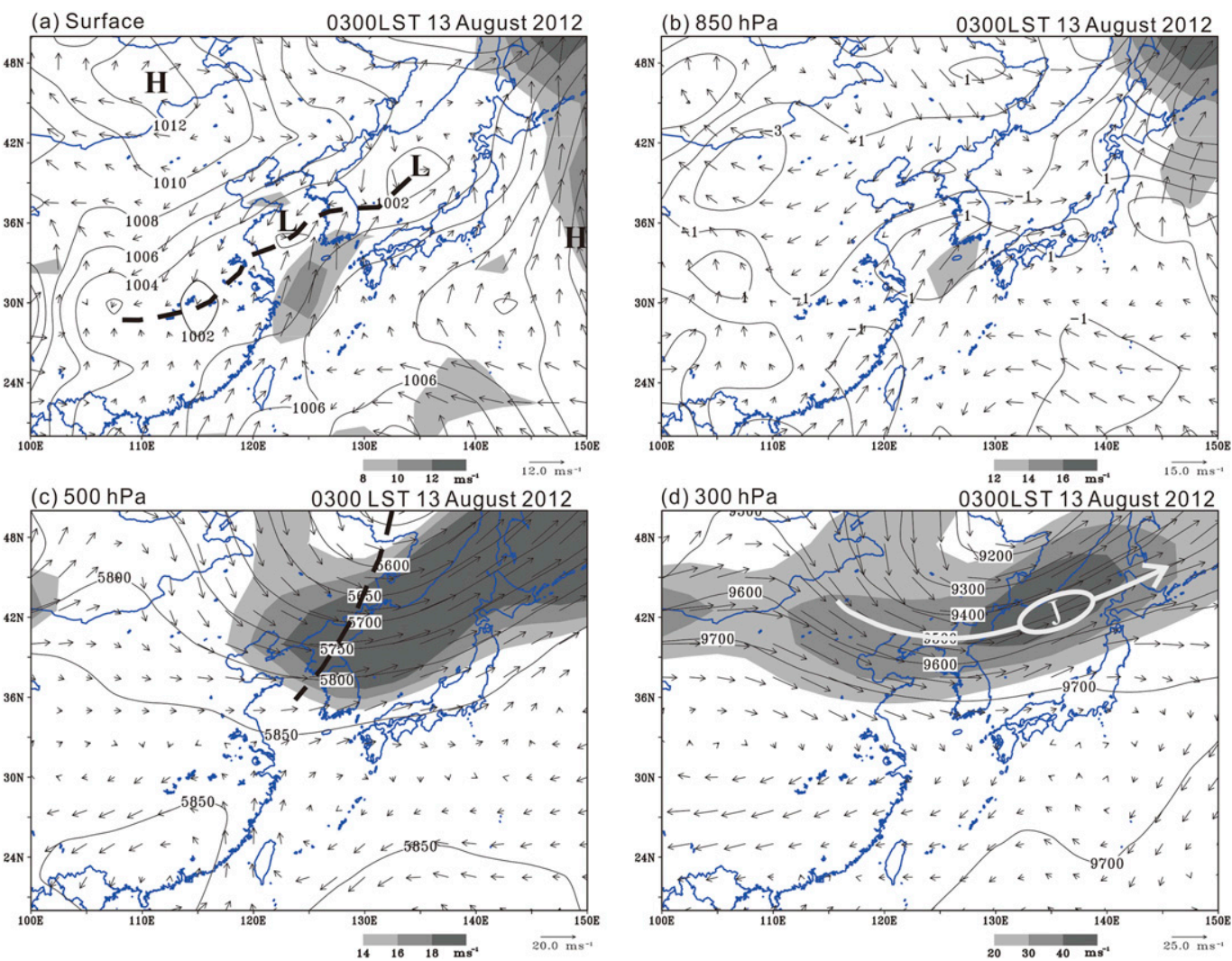

FIG. 3. NCEP-NCAR reanalysis of (a) horizontal wind vectors $\left(\mathrm{m} \mathrm{s}^{-1}\right.$, speed also shaded) and pressure (hPa, contours) at mean sea level; (b) horizontal wind vectors $\left(\mathrm{m} \mathrm{s}^{-1}\right.$, shaded) and temperature advection $\left(10^{-2} \mathrm{~K} \mathrm{~s}^{-1}\right.$, contours) at $850 \mathrm{hPa}$; and (c),(d) horizontal wind vectors $\left(\mathrm{m} \mathrm{s}^{-1}\right.$, shaded) and geopotential height (gpm, contour every $50 \mathrm{gpm}$ ) at (c) 500 and (d) $300 \mathrm{hPa}$ at $0300 \mathrm{LST} 13$ Aug 2012. Thick dashed lines depict the surface front in (a) and the trough in (c). The core and axis of the upper-level jet (ULJ) are also marked in (d). The national boundaries are marked with blue lines.

In particular, a significant rainfall amount exceeding $200 \mathrm{~mm}$ was concentrated within a narrow region in the Gunsan area. The maximum rainfall at the Gunsan station recorded $431.5 \mathrm{~mm}$ of rainfall in less than $12 \mathrm{~h}$ and $100 \mathrm{~mm} \mathrm{~h}^{-1}$ of rainfall intensity in $3 \mathrm{~h}$ (Fig. 2c). Figure $2 \mathrm{~b}$ shows that Tropical Rainfall Measuring Mission (TRMM) 3B42 accumulated rainfall for $12 \mathrm{~h}$. The TRMM 3B42 accumulated rainfall pattern was similar to surface rain but completely covered Korea and extended to the Yellow Sea (Figs. 2a, b).

The horizontal winds and pressure at the mean sea level from the NCEP-NCAR reanalysis at $0300 \mathrm{LST}$ (LST $=$ UTC + 9h) 13 August 2012 are presented in Fig. 3a. A stationary surface front (dashed line in Fig. 3a) extended from southern China to Korea (oriented southwest-northeast) with low pressure and heavy precipitation that occurred near the surface front. Underneath the stationary surface front, a southerly to southwesterly flow prevailed, with strong winds (up to approximately $8 \mathrm{~m} \mathrm{~s}^{-1}$ ) over the East China Sea. In the east of the front, the subtropical high is located in southeastern Japan. The pressure pattern showed that monsoonal southwesterly low-level flow existed along the edge of the subtropical high over Korea. At $850 \mathrm{hPa}$ (Fig. 3b), a southwesterly flow of $\geq 12 \mathrm{~m} \mathrm{~s}^{-1}$ appeared with the criterion often used for the LLJ (J.-H. Jeong et al. 2014).
The warm temperature advection $\left(>0.01 \mathrm{~K} \mathrm{~s}^{-1}\right)$ over the southern Yellow Sea and Korea is higher than that in the surrounding areas. Along with warm air, the LLJ inflows to Korea. At $500 \mathrm{hPa}$ (Fig. 3c), the midtropospheric trough (near $125^{\circ} \mathrm{E}$ ) exhibited a northwestward tilt with geopotential height and west-southwesterly winds $\left(\geq 18 \mathrm{~m} \mathrm{~s}^{-1}\right)$. The upper-level trough (westerly with a speed of $\geq 30 \mathrm{~m} \mathrm{~s}^{-1}$ ) was also present at $300 \mathrm{hPa}$ with a diffuse flow pattern over the ocean east of Korea (Fig. 3d). The Yellow Sea and Korea are located on the southern side of the entrance region of the upper-level jet (ULJ). Direct thermal circulation was generated by the upward motion of the warm air of the southwesterly LLJ from the south and by the downward motion of relatively cold dry air originating from the westerly ULJ from the north (Uccellini and Johnson 1979; Ha and Lee 2007; Seo et al. 2011). This synoptic environment in this study enhanced atmospheric instability and was advantageous for the development of heavy rainfall over Korea.

\section{b. Structure and evolution of MCSs}

Figure 4 presents the reflectivity mosaic (dBZ) with superimposed ERA5 of wind and geopotential height at $850 \mathrm{hPa}$ to analyze the MCSs characteristics from 2100 LST 12 August to 

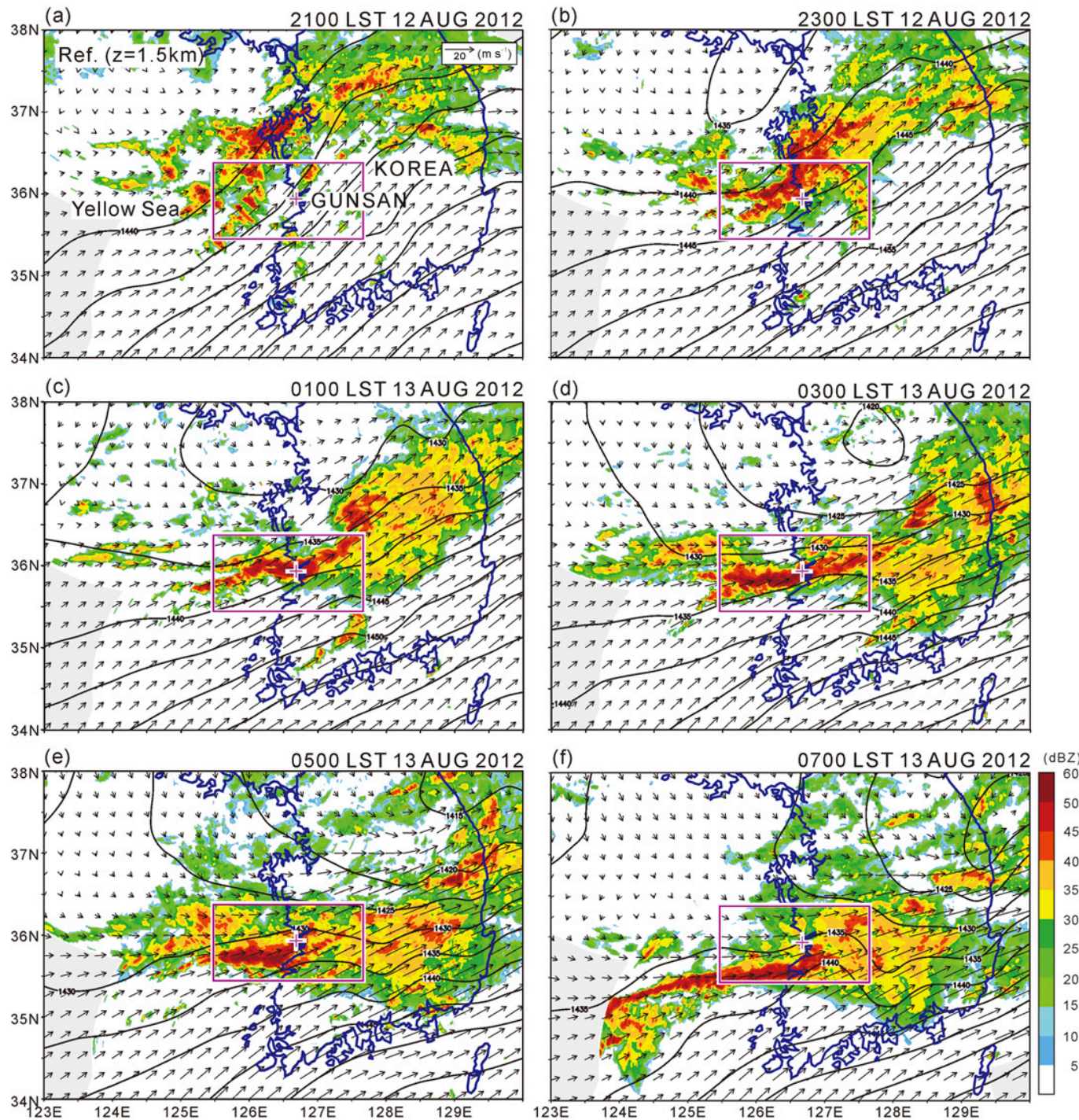

FIG. 4. Horizontal sections of mosaic radar reflectivity (dBZ, color shading, $1.5 \mathrm{~km}$ ) with superimposed ERA5 horizontal wind vectors $\left(\mathrm{m} \mathrm{s}^{-1}\right)$ and geopotential height ( $\mathrm{gpm}$, contours every $\left.5 \mathrm{gpm}\right)$ at $850 \mathrm{hPa}$. The time interval is every $2 \mathrm{~h}$ from 2200 LST 12 Aug to 0700 LST 13 Aug 2012. The national boundaries are marked with blue lines. The solid box indicates the domain for Fig. 5. The Gunsan area is marked by a + symbol.

0700 LST 13 August 2012. During this period, MCSs (meso- $\alpha$ scale, Orlanski 1975) were located south of the stationary front over the Yellow Sea and the central part of Korea. The southward-moving MCSs approached the Gunsan area (marked by the cross in Figs. 4a-b). The MCSs gradually became linear in the east-west direction and were stationary in the Gunsan area for $3 \mathrm{~h}$ (0100-0300 LST, Figs. 4c-d). Subsequently, the linear MCSs moved southward and expanded in length over the Yellow Sea (Figs. 4e-f). This situation is likely to cause heavy rainfall in regions where linear MCSs are stationary (Jang et al. 2014; Lee et al. 2014; Jeong et al. 2016a).

To comprehensively explain the development process of linear MCSs over the Yellow Sea and Gunsan area during the stationary period, Fig. 5 shows a series of horizontal radar reflectivity (KSN CAPPI at 2-km altitude) at 10-min intervals from 0200 to 0310 LST 13 August 2012. By 0140 LST, the linear MCSs (marked by A) appeared perpendicular to offshore Gunsan with a northeast-southwest alignment (Fig. 5a). A convective cell (marked B) was observed on the backside of the linear MCSs. Over time, a convective cell in excess of $40 \mathrm{dBZ}$ (marked by B) expanded in size and moved eastward (Figs. 5b-f). Then, a convective cell (marked by B) merged with the backside of the linear MCSs (marked by A, Figs. $5 \mathrm{~g}-\mathrm{h}$ ). The linear MCSs expanded over the Yellow Sea (marked by C in Fig. 5h).

The linear MCSs were stationary, and cells continued to develop at the western end of the linear MCSs, which remained in the same position during the stationary stage (0100-0359 LST, Figs. 4 and 5). These processes are known as the BB type (e.g., Bluestein and Jain 1985; Schumacher and Johnson 2005). 


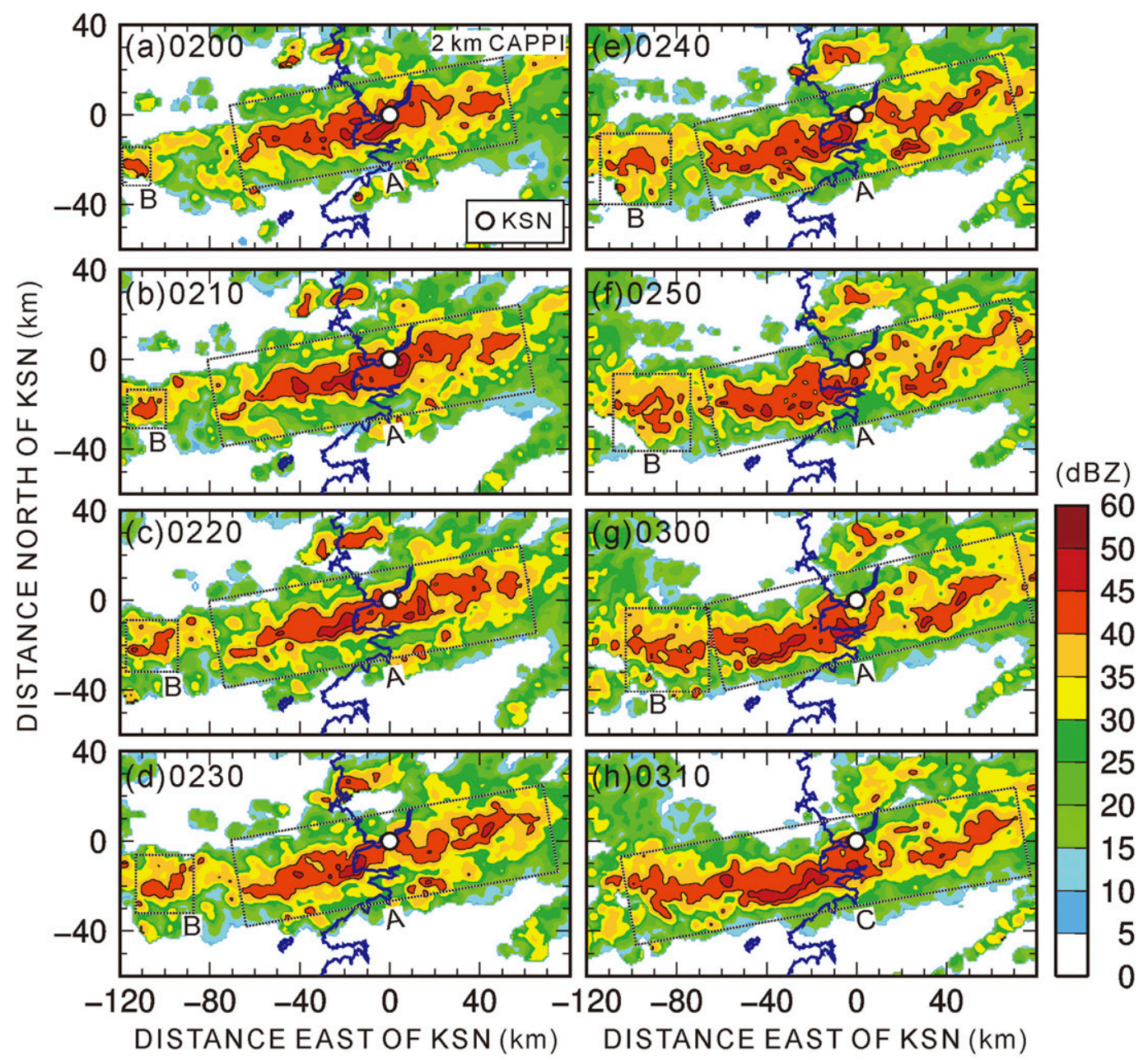

FIG. 5. Series of radar reflectivity (dBZ, color shading) at a height of $2 \mathrm{~km}$ observed by KSN radar at 10-min interval from 0200 to 0310 LST 13 Aug 2012. Selected linear convective systems (convective cells) are labeled by A-C.

The BB patterns of MCSs show that convective cells form upstream of their predecessor and pass over the same region, resulting in local heavy rainfall (Wang et al. 2016). This conceptual model was observed over the Yellow Sea and offshore Gunsan during $3 \mathrm{~h}$ (0100-0359 LST) and coincided with the largest rain peak over the surface rain gauge (see Fig. 2c).

\section{c. Sea surface temperature (SST) over the Yellow Sea}

The linear MCSs were stagnant and propagated over the Yellow Sea. The Yellow Sea between eastern China and Korea is geographically a north-south elongated shallow basin with an area of $404000 \mathrm{~km}^{2}$ and an average water depth of approximately $44 \mathrm{~m}$ (Park et al. 2011). The Yellow Sea is a shallow and small-scale sea compared to the North Atlantic Ocean. Because the Yellow Sea is relatively small-scale, the time scale associated with the air-sea interaction over the Yellow Sea is also relatively short (Park et al. 2011; Jeong and Park 2013; Kim et al. 2017). The SST over the Yellow Sea could act as a causative factor for the exchange of moisture, heat, and momentum across the air-sea interactions. The SST over the Yellow Sea is likely to affect the conditional convective instability of the $\mathrm{PBL}$, resulting in convection over the sea and could contribute to heavy rainfall over Korea. Therefore, it is necessary to examine the distribution of SST fields to understand the convection development process over the Yellow Sea.

Figure 6 shows the climatological mean SST for 1989-2018 and SST on 13 August 2012 from the MGDSST data. The climatological mean SST of the Yellow Sea is approximately $26.5^{\circ}-27.5^{\circ} \mathrm{C}$, but the north (south)-oriented SST is cooler (warmer, Fig. 6a). On 13 August 2012, the SST pattern of the Yellow Sea was elongated in the north-south direction at approximately $27.5^{\circ}-28.5^{\circ} \mathrm{C}$ (Fig. 6b). In particular, an elliptical SST field $\left(>28.5^{\circ} \mathrm{C}\right)$ appeared over the center of the Yellow Sea (approximately $36^{\circ} \mathrm{N}, 124.5^{\circ} \mathrm{E}$ ). This indicates that a local warm pool above $28.0^{\circ} \mathrm{C}$ existed over the Yellow Sea $\left(35^{\circ}-38.5^{\circ} \mathrm{N}\right.$, $\left.123^{\circ}-126^{\circ} \mathrm{E}\right)$, and the temperature anomaly relative to the climatological mean SST indicated that the SST field on 13 August 2012 was anomalously warm $\left(0.5^{\circ}-2^{\circ} \mathrm{C}\right.$, not shown $)$. To examine the impact of the local warm SST field on the intensity of heavy 
(a) 30 years mean $(1989-2018)$

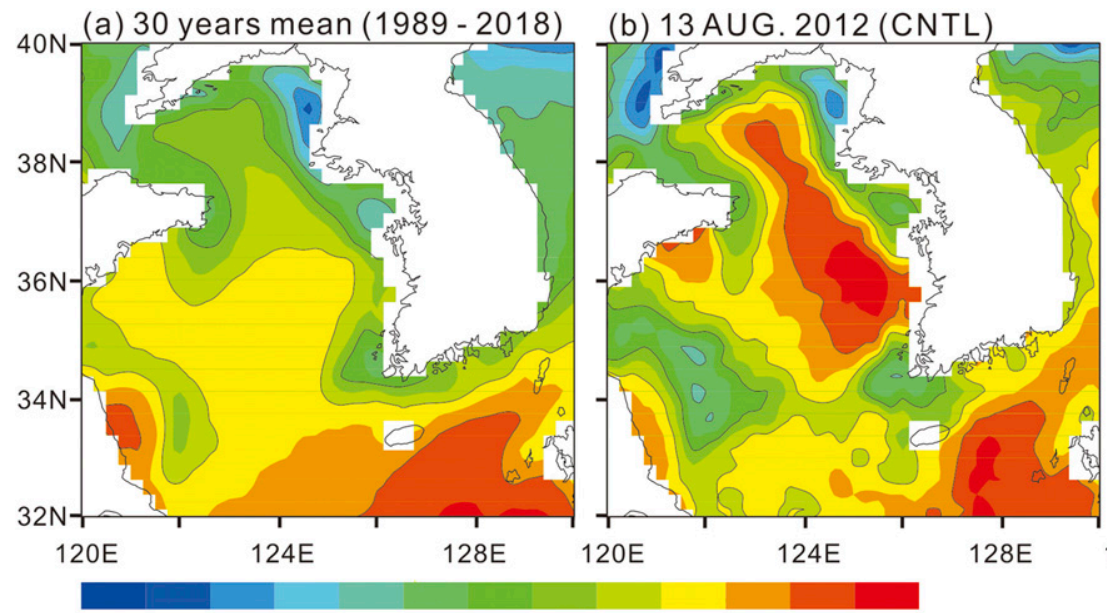

(c) YSST

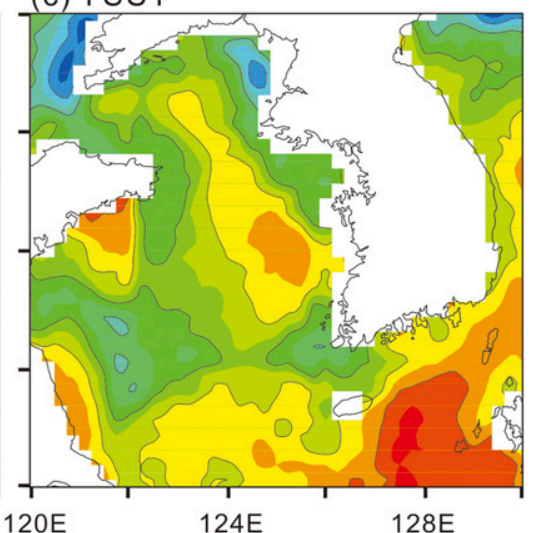

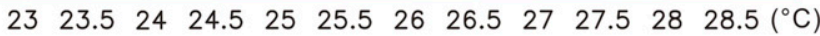

FIG. 6. Sea surface temperature of (a) climatological mean on 13 Aug during 30 years (1989-2018), (b) the day on 13 Aug, and (c) decreasing SST by $1^{\circ} \mathrm{C}$ in the Yellow Sea $\left(34^{\circ}-40^{\circ} \mathrm{N}, 122^{\circ}-126^{\circ} \mathrm{E}\right)$. These SST fields were used in the model experiments in the (b) CNTL and (c) YSST experiments.

rainfall on 13 August 2012, we performed model simulations and a sensitivity test; these are described in the next section.

\section{Model configuration}

\section{a. Description of the Cloud-Resolving Storm Simulator (CReSS) model}

In this study, the Cloud-Resolving Storm Simulator (CReSS) model developed at Nagoya University, Japan (Tsuboki and Sakakibara 2002) was used to simulate the impact of anomalously warmer SST on heavy rainfall. The CReSS model employs fully compressible, nonhydrostatic dynamics and is designed to realistically simulate mesoscale systems at high resolution using explicit cloud microphysics without cumulus parameterization (see Table 1). A terrain-following vertical coordinate with equations for three-dimensional momentum $(u, v, w)$, pressure $(p)$, and potential temperature $(\theta)$ are formulated (Tsuboki and Sakakibara 2007). The microphysics parameterization is an explicit bulk cold-rain scheme incorporated into CReSS based on Lin et al. (1983), Cotton et al. (1986), Murakami (1990), Ikawa and Saito (1991), and Murakami et al. (1994). In the explicit bulk cold-rain scheme, a total of six species (water vapor $q_{v}$, cloud water $q_{c}$, cloud ice $q_{i}$, rain $q_{r}$, snow $q_{s}$, and graupel $q_{g}$ ) and the number concentrations of snow $\left(N_{s}\right)$, cloud ice $\left(N_{i}\right)$, and graupel $\left(N_{g}\right)$ with microphysical processes of nucleation (condensation), sublimation, deposition, evaporation, falling, freezing, melting, conversion, aggregation, collection, and liquid shedding were included.

The subgrid-scale turbulent mixing is parameterized using a 1.5-order closure with turbulent kinetic energy (TKE) prediction (Tsuboki and Sakakibara 2002, 2007). Downward longwave radiation includes the effects of clouds and water vapor, and the downward shortwave radiation absorbed by the ground is considered (Kondo 1976). Nondimensional bulk coefficients were adopted using land surface schemes (Louis et al. 1982).

TABLE 1. Summary of the CReSS model configuration in this study, common to all experiments except alterations in the topography and SST as specified in Table 2.

Projection

Grid spacing

Grid dimension $(x, y, z)$

Min $\Delta z$

Topography and SST

$\mathrm{IC} / \mathrm{BCs}$

Initial time (integration length)

Output frequency

Advection and diffusion

Cloud microphysics

PBL parameterization

Surface processes

Time steps $(\Delta t, \Delta \tau)$

Integration method
Lambert conformal, center at $126^{\circ} \mathrm{E}$, secant at $20^{\circ} / 50^{\circ} \mathrm{N}$

$2 \mathrm{~km} \times 2 \mathrm{~km} \times 0.1-0.5 \mathrm{~km}$

$480 \times 720 \times 50$

$100 \mathrm{~m}$

Real at $1 / 120^{\circ}$ resolution and daily SST with $0.258^{\circ}$ resolution

JMA-MSM every $3 \mathrm{~h}$

0000 UTC 12 Aug 2012 (33 h)

$10 \mathrm{~min}$

Both fourth-order in horizontal and vertical

Bulk cold-rain scheme (mixed-phase with six species)

1.5-order closure with TKE prediction

Energy and momentum fluxes, shortwave and longwave radiation

$\Delta t=4 \mathrm{~s}, \Delta \tau=2 \mathrm{~s}$

Filtered leapfrog for $\Delta t$ (HE-VE), leapfrog and Crank-Nicolson for $\Delta \tau(\mathrm{HE}-\mathrm{VI})$ 
TABLE 2. Design of control experiment (CNTL) and sensitivity tests in this study.

\begin{tabular}{lll}
\hline \hline Expt & \multicolumn{1}{c}{ SST pattern } & Topography \\
\hline CNTL & Observed SST & Real topography \\
YSST & Yellow Sea over $27.5^{\circ} \mathrm{C}$ decreased by $1^{\circ} \mathrm{C}$ & Real topography \\
CNTL_FT & Observed SST & Flat topography of $1 \mathrm{~m}$ \\
YSST_FT & Yellow Sea over $27.5^{\circ} \mathrm{C}$ decreased by $1^{\circ} \mathrm{C}$ & Flat topography of $1 \mathrm{~m}$ \\
\hline
\end{tabular}

A time-splitting scheme (Klemp and Wilhelmson 1978) is adopted in the CReSS model to integrate the acoustic mode terms and gravity mode to improve (or enhance) computational efficiency. The filter leapfrog scheme (Asselin 1972) was used for time-stepping, while the Crank-Nicolson scheme was adopted in the vertical direction for small time steps $(\Delta \tau)$. For parallel computing, the message-passing interface (MPI) is used for data exchange between individual processors.

\section{b. Model output and experimental design}

The CReSS model setup in this study is as follows: The model domain is described in Fig. 1. A control experiment (CNTL) with a full physical model was adopted with a horizontal grid spacing of $2 \mathrm{~km}$, grid dimensions of $480 \times 720$, and 50 vertically stretched layers $(\Delta z=100 \mathrm{~m}$ at the surface and the model top at $25 \mathrm{~km}$ ). For the initial and lateral boundary conditions of the simulations, the output data of the Japan Meteorological Agency mesoscale model (JMA-MSM) with $253 \times 241$ grids (horizontal grid spacing of $5 \mathrm{~km}$ ) and 16 levels were used (Saito et al. 2006). A real topography dataset was obtained from the GTOPO30 30 Arc-Second digital elevation model (DEM). The horizontal resolution of GTOPO30 is approximately $1 \mathrm{~km}$. A daily SST dataset was obtained from the MGDSST at a $0.25^{\circ}$ horizontal resolution (Sakurai et al. 2005; Kurihara et al. 2006). The start time of the simulation was 0900 LST 12 August 2012, and the experiment was integrated for $33 \mathrm{~h}$ with an output every $10 \mathrm{~min}$.

Three sensitivity experiments were designed to separate the effects of SST and terrain on the rainfall pattern on 13 August 2012. The first sensitivity experiment, YSST, was designed to investigate the impact of the warm local SST over the Yellow Sea. The simulation setup was the same as that of the CNTL, but the SST field was designed as shown in Fig. 6c. In this study, to focus on the influence of SST variations over the Yellow Sea, the SST field of the Yellow Sea above $27.5^{\circ} \mathrm{C}\left(34^{\circ}-40^{\circ} \mathrm{N}\right.$, $122^{\circ}-126^{\circ} \mathrm{E}$ ) was decreased by $1^{\circ} \mathrm{C}$ (e.g., reducing the local warm pool) and the SST pattern was retained. Similar modeling experiments with the impact of SST over the Yellow Sea were carried out by J. I. Jeong et al. (2014). They conducted sensitivity experiments with an increase and decrease in SST on heavy snowfall events over the Yellow Sea and showed that the SST deviation affected the rainfall variability for snowfall and rainfall. However, modeling experiments in the warm season were not performed, especially for heavy rainfall events. The second sensitivity experiment, named CNTL_FT, was performed to examine the possibility of the terrain effect. The simulation setup was the same as that for the CNTL, but the topography was changed to a flat area (topography $=1 \mathrm{~m}$ ). In the last sensitivity experiment (YSST_FT), two factors were changed.
The simulation setup was the same as that of the YSST, but the topography was changed to a flat area (topography $=1 \mathrm{~m}$ ). Table 2 provides a summary of the CNTL and the three sensitivity experiments.

\section{Numerical model results}

a. Validation of CNTL and comparison of sensitivity experiments

The simulated 12-h accumulated rainfall distribution (16-28 h of simulation time) from the CNTL experiment was compared with observations to demonstrate the capability of the model results to reproduce the heavy precipitation features. By comparing Figs. 2a and 7a, the CNTL experiment captured the narrow band $(\geq 150 \mathrm{~mm})$ rainfall pattern well, although it overpredicted the rainfall amounts in the center of Korea. The shape of the long and narrow rainfall pattern from the Yellow Sea to Korea is well reproduced in the CNTL run $(\geq 30 \mathrm{~mm}$, around $36^{\circ} \mathrm{N}$, above approximately $125^{\circ} \mathrm{E}$; cf. Figures $2 \mathrm{~b}$ and $7 \mathrm{a}$ ). In Fig. $7 b$, the location of the maximum accumulated rainfall amount in the CNTL experiment $(434 \mathrm{~mm})$ is placed offshore of Gunsan, which is in agreement with the observed maximum accumulated rainfall amount (431.5 mm, marked in Fig. 2a). The time series of hourly rainfall in the CNTL experiment and observations were compared to analyze whether the intensity and timing of heavy rainfall were well reproduced (Fig. 8). The CNTL experiment produced a peak rainfall rate of $156.7 \mathrm{~mm} \mathrm{~h}^{-1}$ and a duration of $3 \mathrm{~h}\left(\geq 80 \mathrm{~mm} \mathrm{~h}^{-1}\right)$, which corresponds closely to observations (peak rainfall rate of $131.5 \mathrm{~mm} \mathrm{~h}^{-1}$, duration of $3 \mathrm{~h}, \geq 80 \mathrm{~mm} \mathrm{~h}^{-1}$ ). Therefore, the CNTL experiment is capable of simulating localized heavy rainfall; thus, this simulation can be applied to evaluate the formation and development of linear MCSs over the Yellow Sea.

The KMA operational forecast model (local data assimilation and prediction system, LDAPS) predicted a large amount of rainfall $(>80 \mathrm{~mm})$ over the Gunsan region, but the model did not produce such extreme rainfall over this region (not shown). This is because the forecast model does not accurately predict the MCS organization and movement over the Yellow Sea. To improve the warm-season QPFs for these types, the storm-scale process and air-sea (land surface) coupled processes should be accurately represented (Luo and Chen 2015; Schumacher 2017; Tai et al. 2020; Kanada et al. 2021).

Figures $7 \mathrm{c}$ and $7 \mathrm{~d}$ show the simulated 12-h accumulated rainfall for the YSST experiment. A narrow band-shaped rainfall area extending from east to west with a maximum rainfall of $408 \mathrm{~mm}$ was simulated. The rainfall pattern was similar to that in the CNTL experiment, but the maximum rainfall was $31 \mathrm{~mm}$ 
(a) CNTL

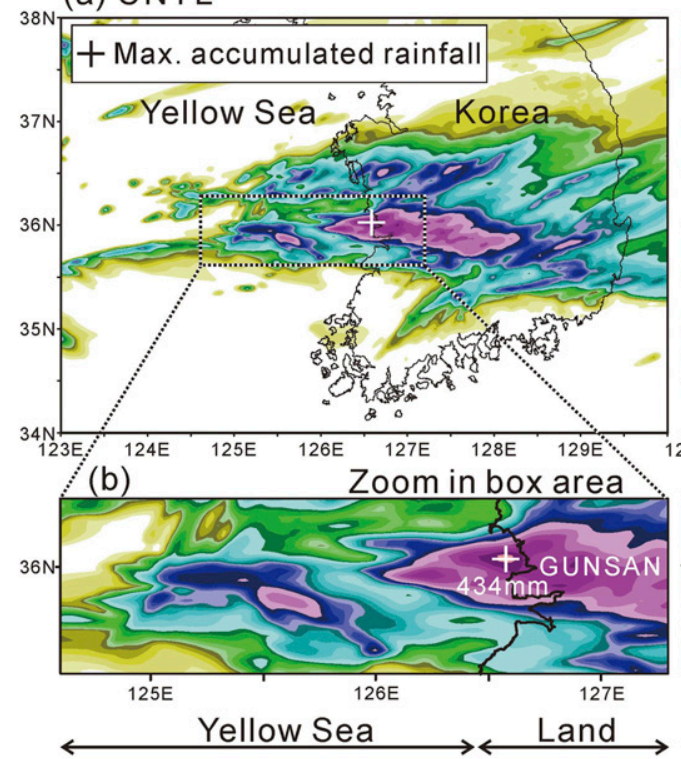

(e) Differences(CNTL-YSST)

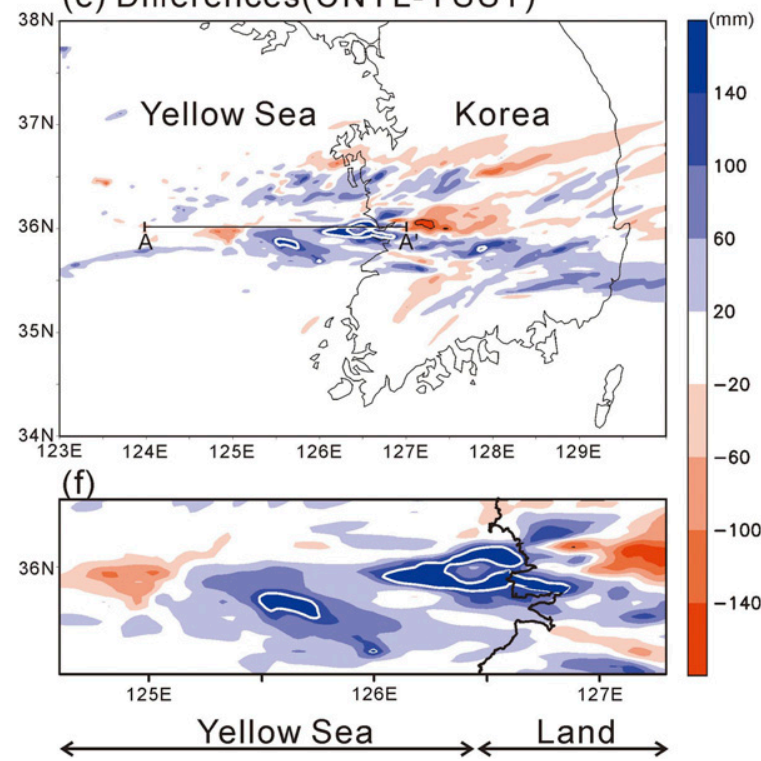

(c) YSST

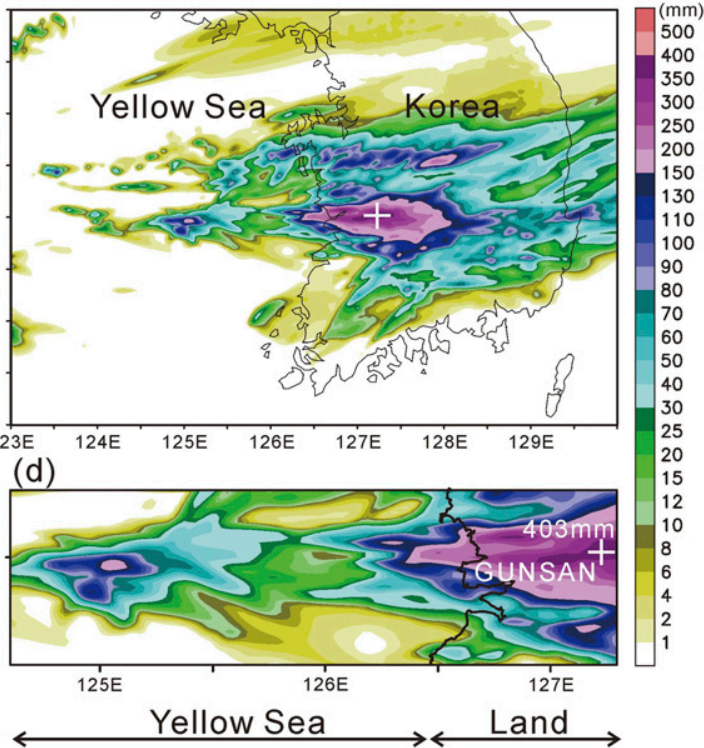

FIG. 7. Accumulated rainfall (mm, color shading) from 2100 LST 12 Aug to 0900 LST 13 Aug 2012 in the (a) CNTL and (c) YSST experiments. (e) Rainfall difference ( $\mathrm{mm}$, color shading) between CNTL and YSST experiments is overlaid. The box in (a) indicates the domain for (b), (d), and (f). The line $A-A^{\prime}$ in (e) indicates the location of the time-longitude Hovmöller diagrams used in Fig. 11. The white lines in (e) and (f) indicate areas where the difference in rainfall is more than $140 \mathrm{~mm}$. The + symbol indicates the location of maximum accumulated rainfall in the experiments. less than that in the CNTL experiment. The location of the maximum rainfall is further inland in the Gunsan area. The differences in the simulated rainfall amount between the two simulations were also examined (Figs. 7e, f). Indeed, the rainfall amount in the CNTL experiment simulated more rainfall overall over the Yellow Sea than in the YSST experiment. In particular, offshore Gunsan showed a maximum rainfall difference of more than $140 \mathrm{~mm}$. The anomalously warm SST could largely enhance heavy rainfall over the Yellow Sea and Gunsan area, as will be shown later.

\section{b. Impact of SST on linear MCSS}

Figures 9 and 10 show the horizontal and vertical structures of the simulated reflectivity and divergence every 30-min during
0330-0430 LST 13 August 2012, to describe the evolution of the simulated linear MCSs. In the CNTL experiment, the MCSs $\left(35.8^{\circ}-36.3^{\circ} \mathrm{N}, 126^{\circ}-127.2^{\circ} \mathrm{E}\right)$ were simulated over the offshore Gunsan and Gunsan areas with east-west alignment at 0330 LST (Fig. 9a). Upstream of MCSs, a convective cell (approximately $36^{\circ} \mathrm{N}, 125.2^{\circ} \mathrm{E}$ ) was formed and moved eastward (Figs. 9a, b). The convective cell merged with the backside of the MCSs at 0430 LST (Fig. 9c). As a result, linear MCSs were developed from the Yellow Sea to the Gunsan area, as newly initiated convective cells merged with linear MCSs. The simulated convergence with a magnitude of more than $-5 \times 10^{-4} \mathrm{~s}^{-1}$ was found at $125.2^{\circ}-127^{\circ} \mathrm{E}$ within the MCSs (Fig. 10). The maximum convergence reached approximately $-30 \times 10^{-4} \mathrm{~s}^{-1}$ at $126.6^{\circ}-127^{\circ} \mathrm{E}$ between the heights of 1 and $5 \mathrm{~km}$ in the offshore 


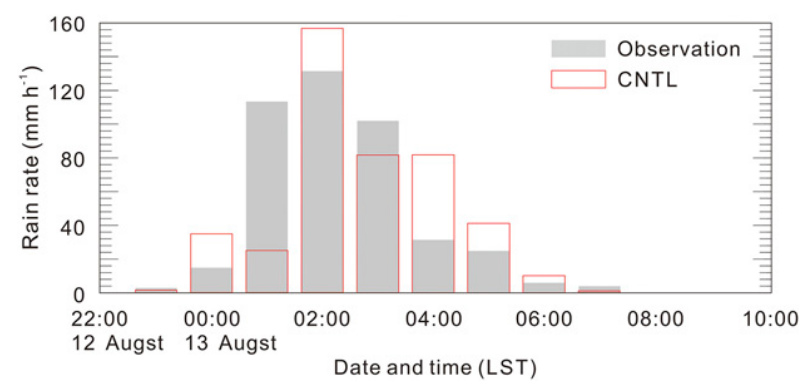

FIG. 8. Time series of hourly rain rate $\left(\mathrm{mm} \mathrm{h}^{-1}\right)$ comparing the observation $\left(35.95^{\circ} \mathrm{N}, 126.59^{\circ} \mathrm{E}\right.$, gray-shaded bars) and CNTL experiment $\left(36.03^{\circ} \mathrm{N}, 126.43^{\circ} \mathrm{E}\right.$, red-outlined bars).

Gunsan and Gunsan areas, and the cold air outflow in linear MCSs was not clear (Fig. 10c). To repeatedly trigger new cells in the BB type, a well-known mechanism is through convectively generated outflow boundary from downdrafts (at the leading edge of the cold pool; e.g., Doswell et al. 1996; Parker and Johnson 2000; Schumacher and Johnson 2005b).

However, the BB type can still be developed due to high humidity at a low level during the mei-yu-baiu-changma season, in environments that are not suitable for strong cold pools (e.g., Yu and Chen 2011; Wang et al. 2016). In the YSST experiment, offshore convection was more intense than convection on land. At 0330 LST, a simulated cell with $Z>45 \mathrm{~dB} Z$ formed (approximately $36^{\circ} \mathrm{N}, 124.8^{\circ} \mathrm{E}$, Figs. 9d and 10d). At 0400 and 0430 LST, the simulated convective cells as a whole remained in a quasi-stationary position (Figs. 9e, f and 10e, f). Around the offshore Gunsan and Gunsan areas $\left(126.2^{\circ}-127^{\circ} \mathrm{E}\right)$, the maximum convergence reached approximately $-30 \times 10^{-4} \mathrm{~s}^{-1}$ between the heights of approximately $6 \mathrm{~km}$ (Fig. 10f).

The Hovmöller diagram analysis was used to examine the differences in motion and evolution of the linear MCSs over the Yellow Sea between the CNTL and YSST. Figure 11 displays the simulated reflectivity (at $1423 \mathrm{~m}$ ) and divergence (at $351 \mathrm{~m}$ ) variations over time. The Hovmöller diagram for the cross section is along with precipitation maxima $\left(36^{\circ} \mathrm{N}, 124.5^{\circ}-\right.$ $127^{\circ} \mathrm{E}, \mathrm{A}-\mathrm{A}^{\prime}$ in Fig. 7e) during the heavy precipitation period of 0000-0800 LST on 13 August 2012. For the CNTL experiment, linear MCSs $(Z>45 \mathrm{~dB} Z)$ occurred over the Yellow Sea and moved to Korea with continuous eastward propagation (0300-0600 LST, $125^{\circ}-127^{\circ} \mathrm{E}$, Fig. 11a). The simulated convergence in the lower atmosphere (above $-2 \times 10^{-4} \mathrm{~s}^{-1}$ ) was consistent the linear MCSs $\left(0300-0600 \mathrm{LST}, 125^{\circ}-127^{\circ} \mathrm{E}\right.$, in Fig. 11c). For the YSST experiment, linear MCSs $(Z>45 \mathrm{~dB} Z)$ occurred over the Yellow Sea with eastward propagation (Fig. 11b), but linear MCSs developed more discontinuously than the CNTL experiment (0400-0500 LST, $\left.125.6^{\circ}-126.1^{\circ} \mathrm{E}\right)$. The convergence of the YSST experiment in the lower atmosphere was not consistent with the position where the linear MCSs were compared to the CNTL experiment (0100-0400 LST, $126^{\circ}-126.6^{\circ}$ E, Fig. 11d).

Previous studies have shown that the supply of heat and moisture over the ocean around East Asia contributes to the development of MCSs through decreased atmospheric stability (Meng et al. 2005; Moteki and Manda 2013; Sato et al. 2016;
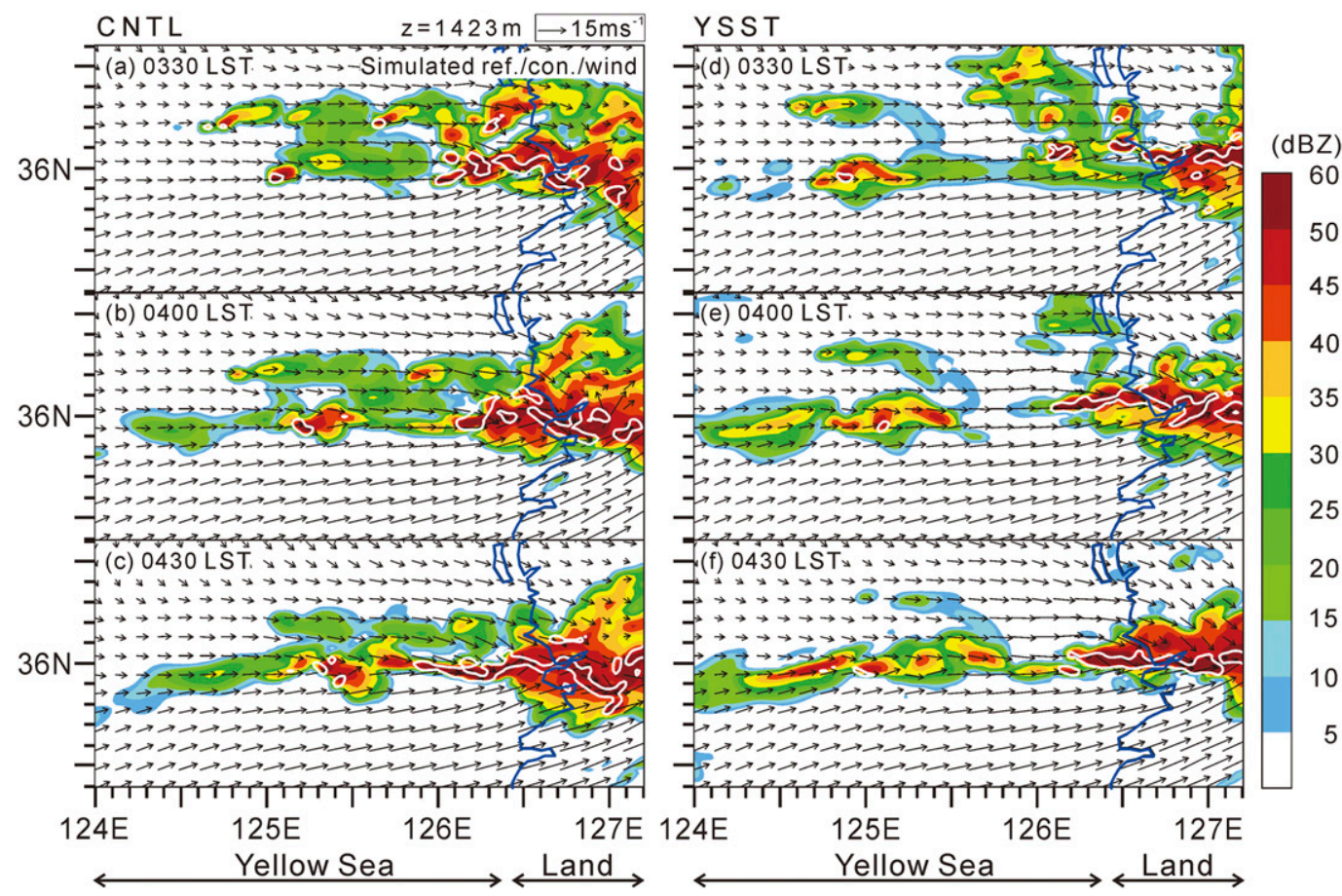

FIG. 9. Simulated reflectivity ( $\mathrm{dBZ}$, color shading), convergence $\left(1 \times 10^{-4} \mathrm{~m} \mathrm{~s}^{-1}\right.$, white solid lines), and horizontal wind field ( $\mathrm{m} \mathrm{s}^{-1}$, vectors) at $1423 \mathrm{~m}$ in (left) CNTL experiment and (right) YSST experiment at 30 min intervals from 0330 to 0430 LST 13 Aug 2012. The blue solid line is the coastline. 
(a)

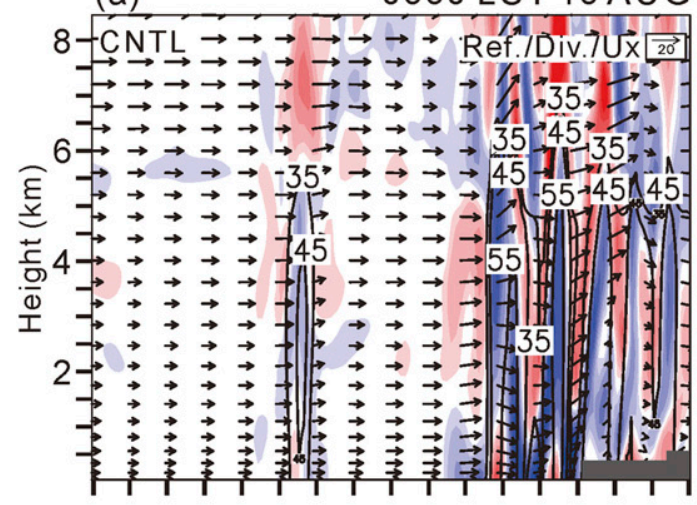

(b)

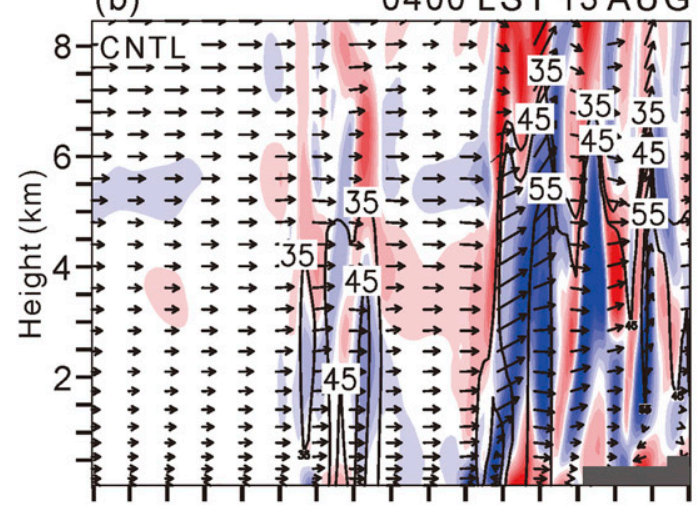

(c)

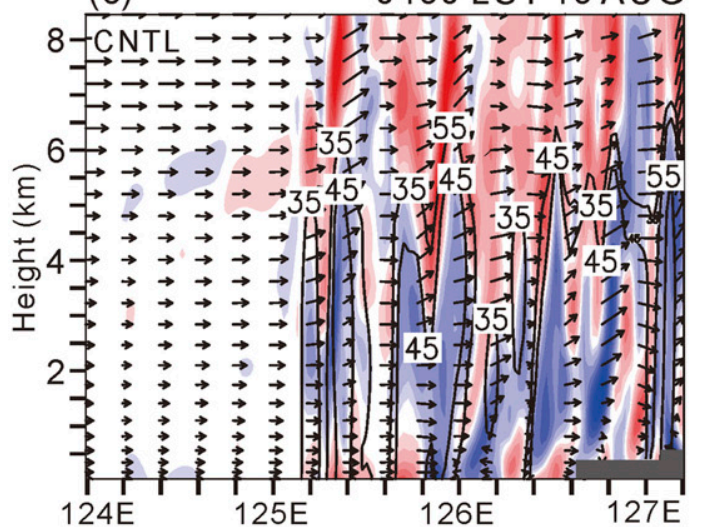

0330 LST 13 AUG

(d)

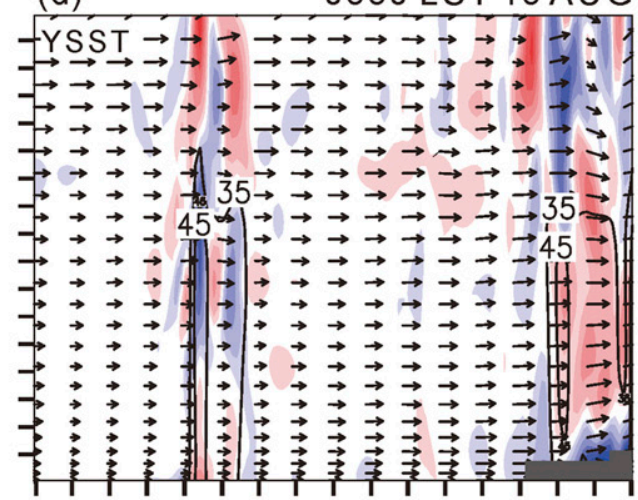

(e)

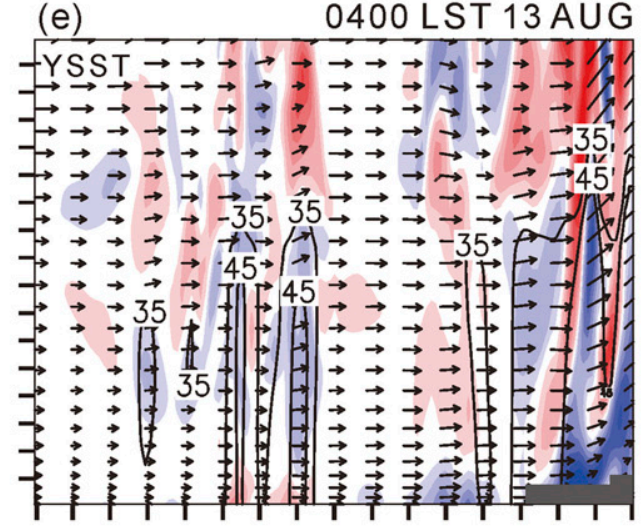

(f)

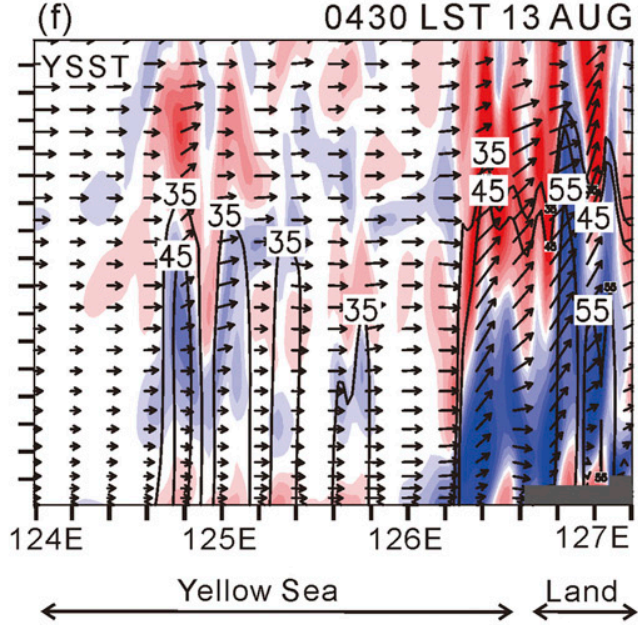

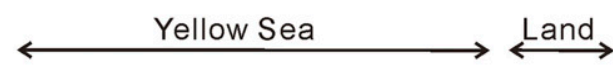

$$
-30-25-20-15-10-5 \quad-2 \quad 2 \quad 5 \quad 10 \quad 15 \quad 20 \quad 25 \quad 30\left(10^{-4} s^{-1}\right)
$$

FIG. 10. Vertical cross sections (transect A-A' in Fig. 7e) of model-simulated reflectivity (dBZ, black line), convergence/divergence $\left(10^{-4} \mathrm{~s}^{-1}\right.$, color shading, negative for convergence), and wind vectors ( $\left.\mathrm{m} \mathrm{s}^{-1}\right)$ in (left) CNTL and (right) YSST at 30-min intervals from 0330 to 0430 LST 13 Aug 2012.

Hosoda and Sakaida 2016). Following these studies, we examined the simulated latent heat flux (LHF) to investigate moisture evaporation from the Yellow Sea (Fig. 12). The LHF data of the CNTL experiment exceeded $30 \mathrm{~W} \mathrm{~m}^{-2}$ at all times during the development of the MCSs, and the LHF regions exceeding $180 \mathrm{~W} \mathrm{~m}^{-2}$ appeared over the Yellow Sea (Figs. 12a-c). The LHF of the YSST experiment exceeded $30 \mathrm{~W} \mathrm{~m}^{-2}$, but no area exceeded $180 \mathrm{~W} \mathrm{~m}^{-2}$ over the Yellow Sea (Figs. $12 \mathrm{~d}-\mathrm{f}$ ). 

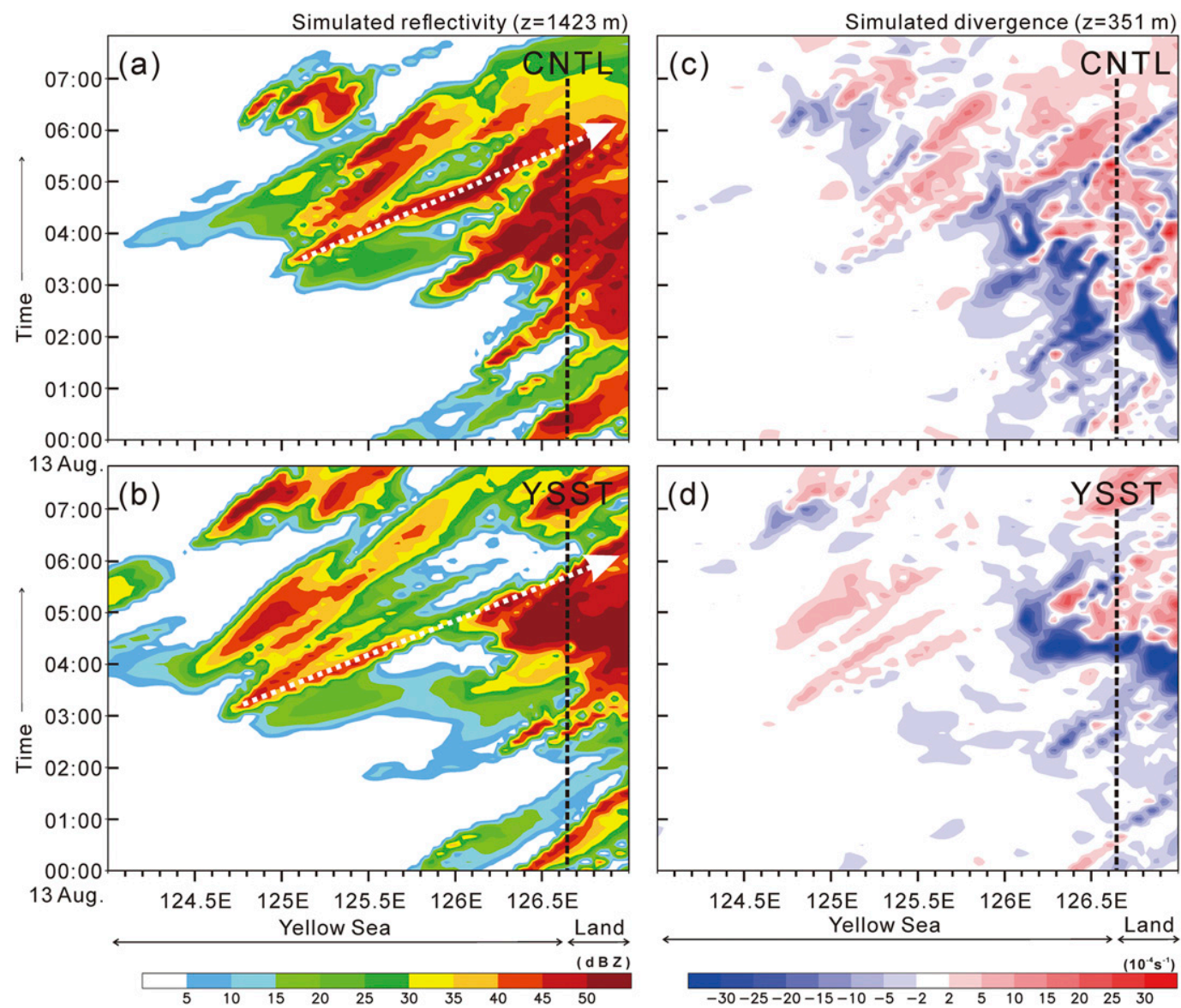

FIG. 11. Time-longitude Hovmöller diagrams (transect A-A' in Fig. 7e) of model-simulated (a),(b) reflectivity and (c),(d) divergence for (left) CNTL and (right) YSST runs at 10-min intervals from 0000 to 0800 LST 13 Aug 2012. The black dashed line shows the coastline and white dashed arrows indicated the propagation.

The LHF data averaged from 0000 to 0800 LST 13 August 2012 along $36^{\circ} \mathrm{N}$, are shown in Fig. 13. The mean values of LHF in the CNTL experiment were approximately $5-35 \mathrm{~W} \mathrm{~m}^{-2}$ higher than in the YSST experiment overall (except for $125.4^{\circ}-125.65^{\circ} \mathrm{E}$ ). The LHF from the Yellow Sea was larger in the CNTL experiment. Given a sufficient amount of water vapor, the low-level boundary would enhance thermal instability over the warmer SST in the Yellow Sea.

To investigate the convective instability in the PBL, Fig. 14 shows the Hovmöller diagram of the simulated convective available potential energy (CAPE) from 0000 to 0800 LST 13 August 2012. In the CNTL experiment (Fig. 14a), the maximum CAPE $\left(\geq 3300 \mathrm{~J} \mathrm{~kg}^{-1}\right)$ was observed in the Yellow Sea $(0100-0300 \mathrm{LST}$, $125.1^{\circ}-125.8^{\circ} \mathrm{E}$ ), whereas the CAPE in the YSST experiment was significantly reduced, by approximately $600 \mathrm{~J} \mathrm{~kg}^{-1}$, compared to the CNTL experiment (Fig. 14b). These facts indicate that convective instability was more strongly associated with warmer water in the CNTL than in the YSST experiment.

\section{c. Simulations with flat topography}

To isolate the SST factor on the rainfall from the terrain factor, we performed additional experiments for CNTL_FT (same as the CNTL experiment, but the topography is flat) and YSST_FT (same as the YSST experiment, but the topography is flat) were performed (cf. section $4 \mathrm{~b}$ ). If the simulation results of CNTL_FT and YSST_FT are similar to the simulation results of CNTL and YSST with full topography, it will support the argument for the enhancement of rainfall over the Yellow Sea and Gunsan area due to the local warm SST.

Figure 15 shows the 12-h accumulated rainfall for flat topography. The accumulated rainfall over the land in the CNTL_FT and YSST_FT experiments (flat topography) were less than those in the CNTL and YSST experiments, respectively (Figs. 15a-d and $7 \mathrm{a}-\mathrm{d}$ ). This suggests that the heavy rainfall over the land is caused by the low-level humid airflow interaction with the topography (e.g., Lee et al. 2012). When we compared the accumulated rainfall amounts in both flat experiments, the CNTL_FT experiment simulated more rainfall over the Yellow Sea. On the other hand, the YSST_FT experiment had more rainfall over land. This means that the effect of the local warm SST is independent of the terrain factor. In addition, the location of the maximum accumulated rainfall in the CNTL_FT and YSST_FT experiments shifted southeast from their locations of the maximum accumulated rainfall in the CNTL and YSST experiments 

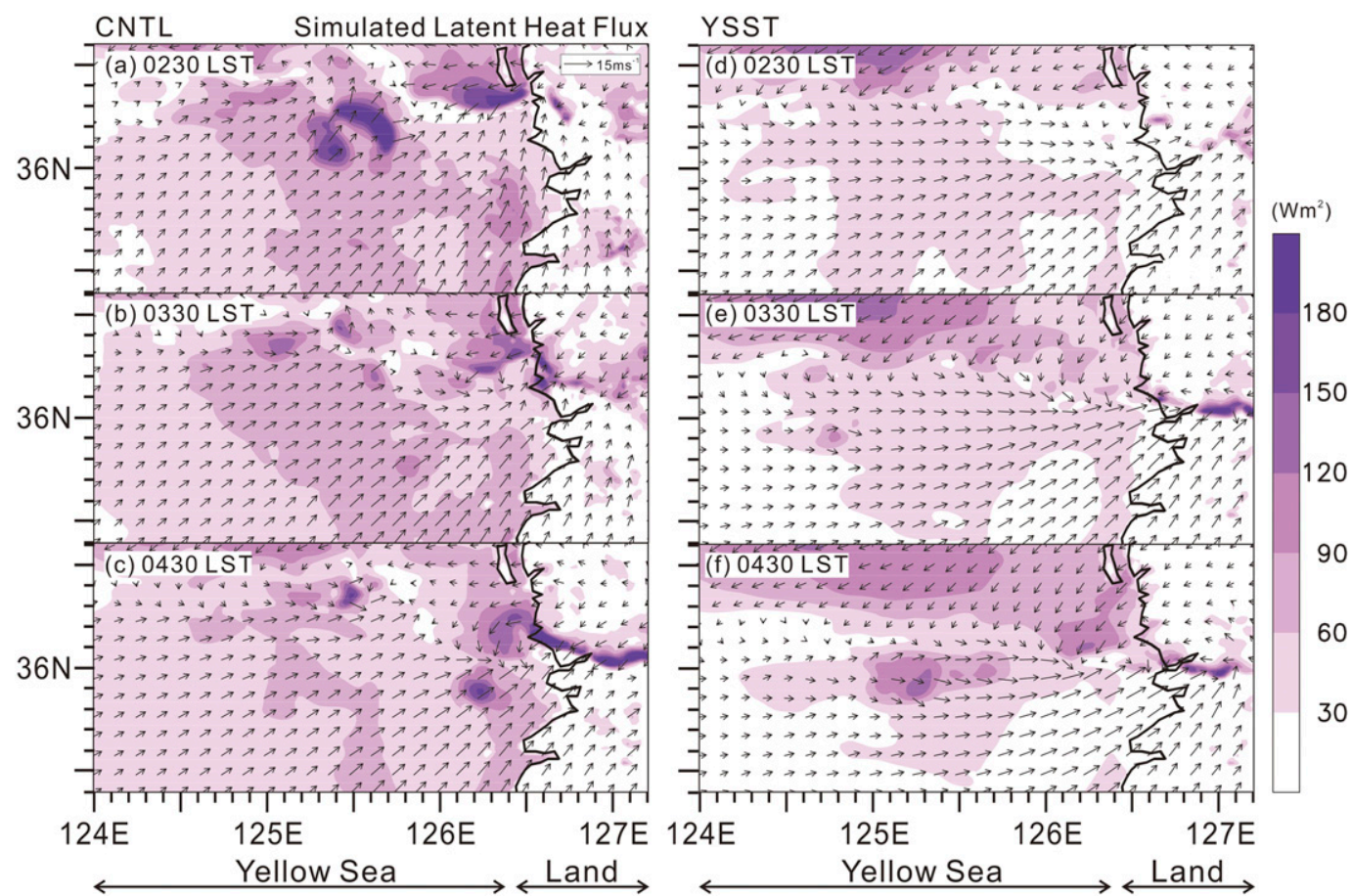

FIG. 12. Horizontal distribution of simulated latent heat flux in (left) CNTL and (right) YSST at 1-h intervals from 0230 to 0430 LST 13 Aug 2012. The black solid line is the coastline.

(see cross symbols at Fig. 15f). The maximum accumulated rainfall amount in the YSST_FT experiment $(369 \mathrm{~mm})$ was higher than that in the CNTL_FT experiment $(286 \mathrm{~mm})$. The accumulated rainfall in the CNTL_FT was distributed from the Yellow Sea to the coastal region. However, the region with the highest rainfall in the YSST_FT is more intense and concentrated over the coastal region, suggesting that coastal precipitation is a blending effect of land-sea interactions. Previous studies showed that land-sea interactions on the west coast of Korea have contributed to the development of the nearshore MCSs (e.g., Lee et al. 2014, 2019).

Figure 16 displays the Hovmöller diagram analysis with flat topography, showing that the enhancement of linear MCSs over the Yellow Sea is influenced by the local warm SST. Similar to when the topography is present, the linear MCSs in CNTL_FT moved from offshore Gunsan to Gunsan area with eastward propagation $\left(0400-0500 \mathrm{LST}, 125.8^{\circ}-127^{\circ} \mathrm{E}\right.$, Fig. 16a). For the YSST_FT experiment, the linear MCSs occurred over the Yellow Sea with eastward propagation and developed discontinuously (0400-0500 LST, $125.8^{\circ}-126.3^{\circ} \mathrm{E}$, Fig. 16b). This development of linear MCSs is weaker than that of the CNTL and YSST experiments, but the pattern is similar. Linear MCSs can be developed by the inflow of strong low-level moist airflow from the sea and terrain-induced upward motion on land (Lee et al. 2012). If topography is reduced or flat, the low-level convergence zone is weaker than the full topography (Wang et al. $2005)$. In the Gunsan area $\left(126.65^{\circ}-127^{\circ} \mathrm{E}\right)$ of the CNTL_FT and YSST_FT experiments with flat topography, the intensity, distribution of reflectivity $(Z>45 \mathrm{dBZ})$, and convergence were weaker than in the CNTL and YSST experiments (Fig. 11).
In particular, the intensity and distribution of reflectivity in the offshore Gunsan $\left(126.3^{\circ}-126.65^{\circ} \mathrm{E}\right)$ were reduced in the CNTL_FT and YSST FT experiments. It was shown that the development of linear MCS in offshore Gunsan is affected by two factors (SST and terrain). We will examine the interactions between the two factors (SST and terrain) in the following section.

\section{d. Factor separation}

\section{1) Methodology}

To reveal the synergy between the SST and terrain factors, as well as to isolate the effects of the factors, we applied the factor separation (FS) method (Stein and Alpert 1993; Alpert and Sholokhman 2011). The FS method is used for factor

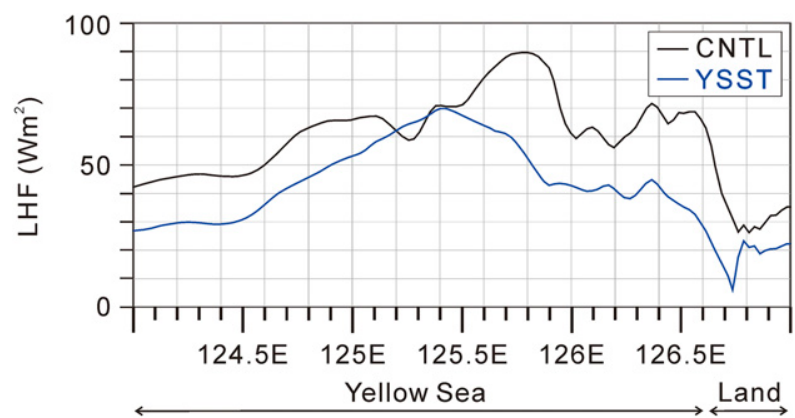

FIG. 13. Latent heat flux (LHF, $\mathrm{W} \mathrm{m}^{-2}$ ) averaged from 0000 to 0800 LST along $36^{\circ} \mathrm{N}$. The solid black and blue lines show the results in CNTL and YSST, respectively. 
(a) CNTL

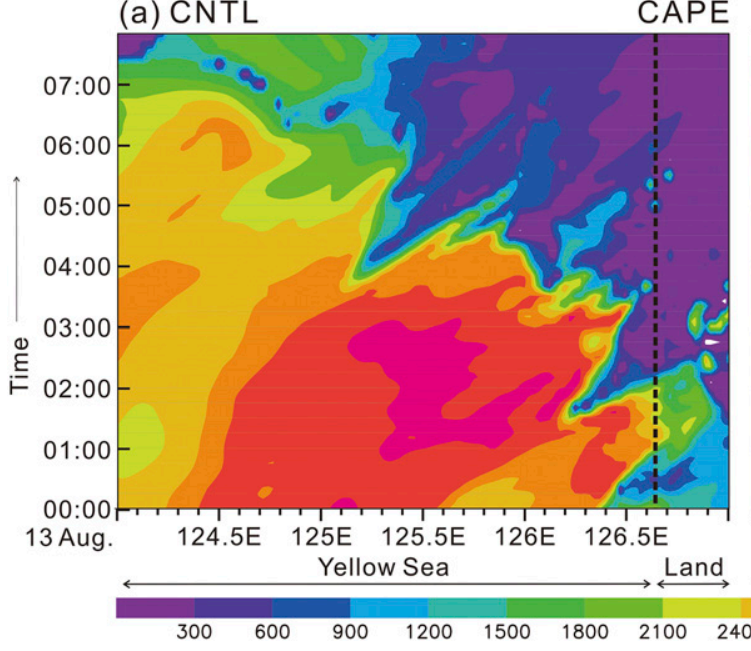

\section{(b) YSST}

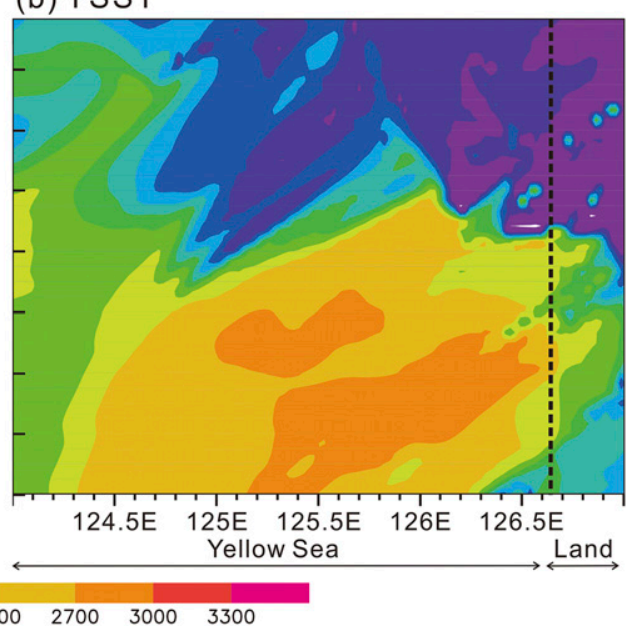

FIG. 14. Time-longitude Hovmöller diagrams (transect A-A' in Fig. 7e) of model-simulated CAPE for (a) CNTL and (b) YSST experiments at 10-min intervals from 0000 to 0800 LST 13 Aug 2012. The black dashed line shows the coastline.

separation in numerical simulations, and its critical element shows is the derivation of the interaction effects between the factors. The FS method was used to quantify the impact of different model physical schemes on the warm season rainfall (Jankov et al. 2005), to isolate the role of the SST front and topography in heavy rainfall (Toy and Johnson 2014), and to study the total effect of orography and latent heat on rainfall (Romero et al. 2000). A simple expression for the factors is formulated in the equations of Stein and Alpert (1993):

$$
\hat{f}_{i_{1} i_{2} i_{3}, i_{l}}=\sum_{m=0}^{l}(-1)^{l-m}\left[\sum_{j_{1}, j_{2}, j_{3}, \ldots, j_{m}=i_{1}, i_{2}, i_{3}, \ldots, i_{m}}^{i_{l-m+1}, i_{l-m+2}, \ldots, i_{l}} f_{j_{1} j_{2} j_{3} \ldots j_{m}}\right],
$$

where the inner sum is over all groups of $m$ sorted indices $j_{1}$, $j_{2}, j_{3}, \ldots, j_{m}$ chosen from $l$ indices $i_{1}, i_{2}, i_{3}, \ldots, i_{l}$, where $0 \leq 1 \leq n$. The $f$ term indicates the variance (depending on $n$ factors), and $\hat{f}$ indicates the effect on $f$. To isolate the influence of $n$ factors, one needs $2^{n}$ simulations, two factors (SST and terrain in this study), thus, requiring four simulations for a complete separation. Following Eq. (2), we use a notation where the subscripts denote the factors (denoted by $f$ terms) as follows:

$f_{0}$ : Rainfall amount of YSST_FT experiment,

$f_{1}$ : Rainfall amount of CNTL_FT experiment (the SST factor),

$f_{2}$ : Rainfall amount of YSST experiment (the terrain factor),

$f_{12}$ : Rainfall amount of CNTL experiment (the SST and terrain factors).

The solution to (3)-(6) yields may be algebraically combined to yield the isolated effects on the considered field by the local warm SST, terrain, and their synergism (denoted by $\hat{f}$ terms, Table 3).

The sole contribution to the rainfall from the SST factor is

$$
\begin{aligned}
\hat{f}_{1} & =f_{1}-f_{0} \\
& =\text { Rainfall difference between CNTL_FT and YSST_FT. }
\end{aligned}
$$

The sole contribution to the rainfall from the terrain factor is

$$
\begin{aligned}
\hat{f}_{2} & =f_{2}-f_{0} \\
& =\text { Rainfall difference between YSST and YSST_FT. }
\end{aligned}
$$

The contribution to the rainfall from the synergistic effects of the SST and terrain factors is

$$
\begin{aligned}
\hat{f}_{12}= & f_{12}+f_{0}-f_{1}-f_{2} \\
= & \left(f_{12}-f_{2}\right)-\left(f_{1}-f_{0}\right) \\
= & \text { (Rainfall difference between CNTL and YSST) minus } \\
& \text { (Rainfall difference between CNTL_FT and YSST_FT). }
\end{aligned}
$$

\section{2) ISOLATION AND SYNERGY OF FACTORS ON RAINFALL}

Figure 17 shows the components of the factor separation analysis related to accumulated rainfall from 0000 LST 13 August to 1200 LST 13 August 2012. The "SST" component (Figs. 17a, b) indicates the enhancement of precipitation over the Yellow Sea and part of the Gunsan area where the topography is flat. The most significant contribution to the rainfall over the Gunsan area is from the "TERRAIN" component (a contribution of $>140 \mathrm{~mm}$, marked white lines in Figs. 17c, d). The "SYNERGY" component (Figs. 17e, f) is a positive contribution to the rainfall from the Yellow Sea to the Gunsan area, especially the coastline (marked white 
(a) CNTL_FT
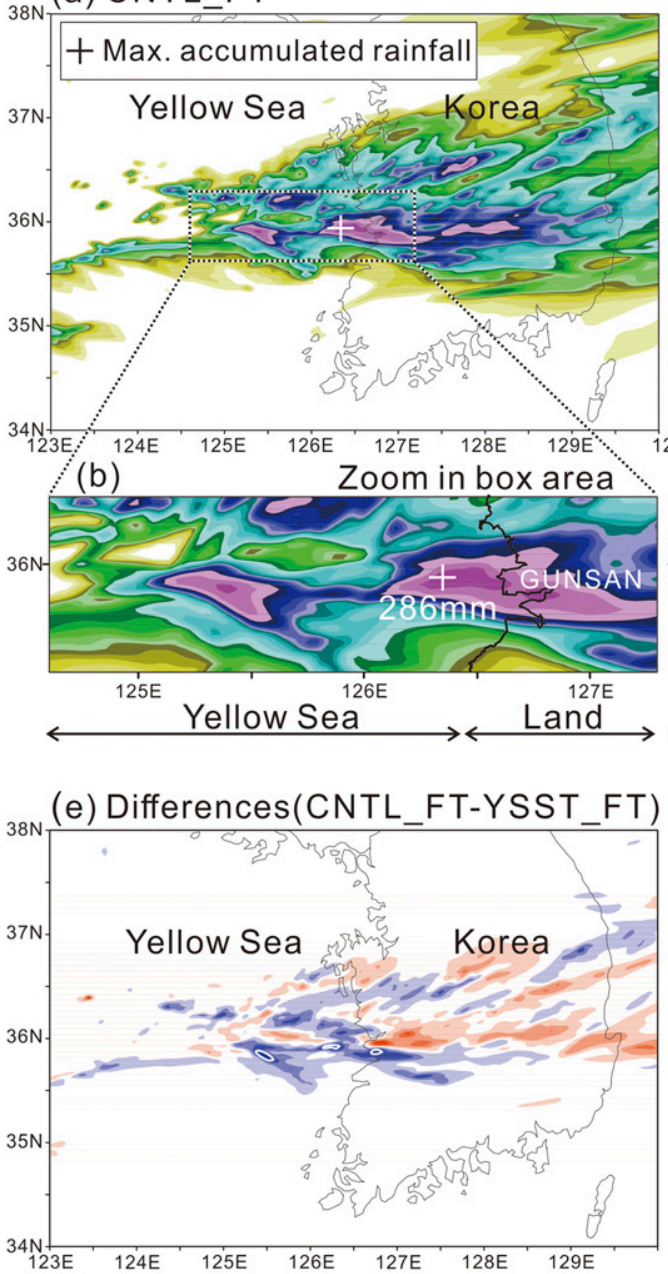

(f)

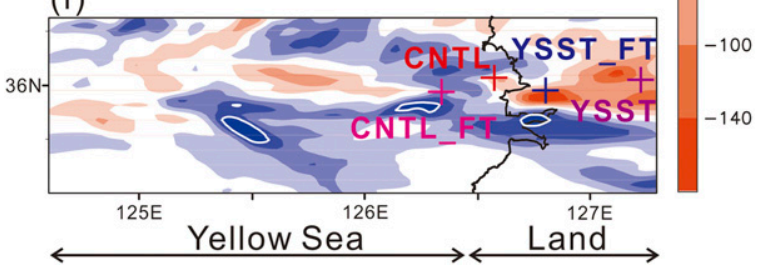

(c) YSST_FT
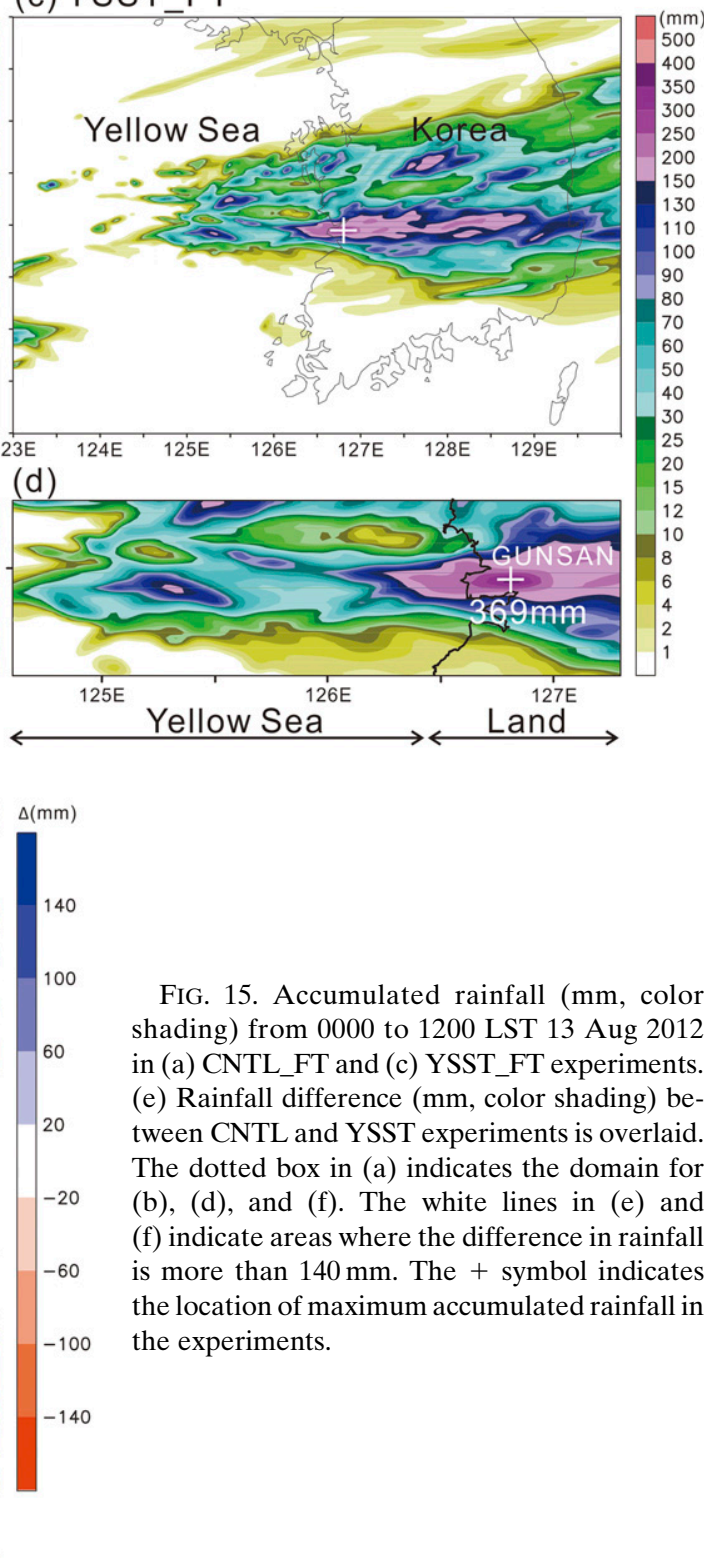

FIG. 15. Accumulated rainfall (mm, color shading) from 0000 to 1200 LST 13 Aug 2012 in (a) CNTL_FT and (c) YSST_FT experiments. (e) Rainfall difference ( $\mathrm{mm}$, color shading) between CNTL and YSST experiments is overlaid. The dotted box in (a) indicates the domain for (b), (d), and (f). The white lines in (e) and (f) indicate areas where the difference in rainfall is more than $140 \mathrm{~mm}$. The + symbol indicates the location of maximum accumulated rainfall in the experiments. lines) because of a synergistic coupling between the SST and topography.

\section{Summary and discussion}

In the present study, an extreme rainfall event on 13 August 2012 was studied to investigate the processes of heavy precipitation and contributing factors for the development of linear mesoscale convective system (MCS) over the Yellow Sea and Gunsan area. The large-scale environment and structure of the linear MCS were examined based on observational data and reanalysis data. High-resolution simulations of the extreme event enabled a detailed investigation of the linear MCS formation and development process. The effects of SST and terrain on MCS-produced extreme rainfall were also highlighted through sensitivity experiments. The results of this study are summarized as follows:

Synoptic analysis showed that extreme rainfall occurred south of the stationary front. The southwesterly low-level jet (LLJ) transported warm and moist air, and the upper-level trough amplified the development of convection. The MCS model is the back-building (BB) type, in which the convective cells produce an upstream of their predecessor and pass over the same region. The synoptic environment and MCS mode are advantageous for extreme rainfall over the Yellow Sea. The SST field of the Yellow Sea in this event was $1{ }^{\circ} \mathrm{C}$ higher than the 30-yr climatological mean and a local warm pool $\left(>28.5^{\circ} \mathrm{C}\right)$. 

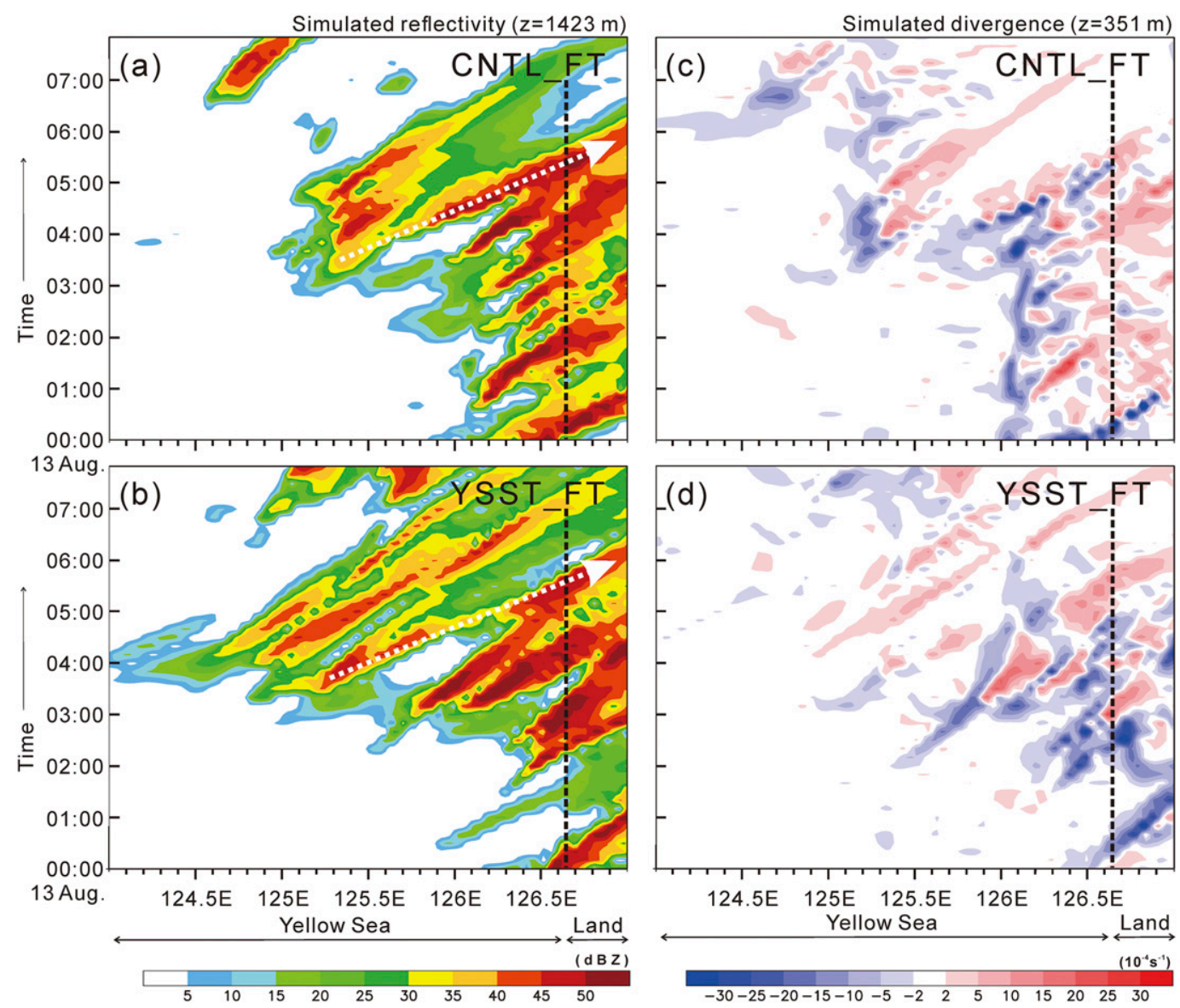

FIG. 16. Time-longitude Hovmöller diagrams (transect $\mathrm{A}-\mathrm{A}^{\prime}$ in Fig. 7e) of model-simulated (a),(b) reflectivity and (c),(d) divergence for (top) CNTL_FT and (bottom) YSST_FT runs at 10-min intervals from 0000 to 0800 LST 13 Aug 2012. The black dashed line shows the coastline and white dashed arrows indicates the propagation.

We performed model simulations and three sensitivity experiments including two factors (local warm SST and terrain) to examine the impact of the local warm SST field on the intensity of heavy rainfall on 13 August 2012. Three sensitivity experiments were designed for YSST (SST field of Yellow Sea above $27.5^{\circ} \mathrm{C}$ decreased by $1^{\circ} \mathrm{C}$ ), CNTL_FT (CNTL with a flat terrain), and YSST_FT (YSST with a flat terrain). Using the CReSS model at 2-km horizontal grid spacing, the control simulation (CNTL) successfully reproduced the observed extreme rainfall event, with the resulting rainfall closely matching the observation. The linear MCSs formed over the Yellow Sea and continuously moved eastward. The linear MCS was simulated as the BB type, in agreement with the observations. The local warm SST increases the latent heat flux (LHF) over the Yellow Sea related to air-atmosphere interaction, which moistens and destabilizes the low-level atmosphere (below $\sim 2 \mathrm{~km}$ ). This results in enhanced low-level convergence and an increase in the convection intensity. This resulted in extreme rainfall over the Yellow Sea and the coast of the Gunsan area.

In the sensitivity experiment, both with and without the presence of topography, the rainfall was considerably stronger over the Yellow Sea when local warm SST was present. The most significant contribution to rainfall in the Gunsan area was the topographic effects. The synergistic coupling

TABLE 3. Effects of the factor separation analysis

\begin{tabular}{cllcl}
\hline \hline Factor & Name & & Description & Calculation \\
\hline$\hat{f}_{1}$ & SST & Sole contribution to the rainfall from the effect of local warm SST & $\hat{f}_{1}=f_{1}-f_{0}$ \\
$\hat{f}_{2}$ & TERRAIN & Sole contribution to the rainfall from the effect of terrain & $\hat{f}_{22}=f_{2}-f_{0}$ \\
$\hat{f}_{12}$ & SYNERGY & Contribution to the rainfall from the synergistic effects of the local warm SST and terrain & $\hat{f}_{12}=f_{12}+f_{0}-f_{1}-f_{2}$ \\
\hline
\end{tabular}


(a) "SST" componet

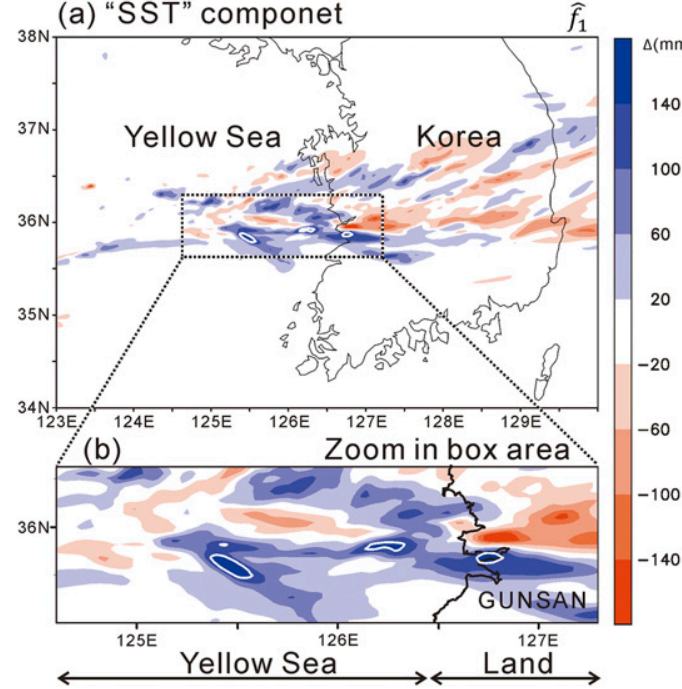

(e) "SYNERGY" componet

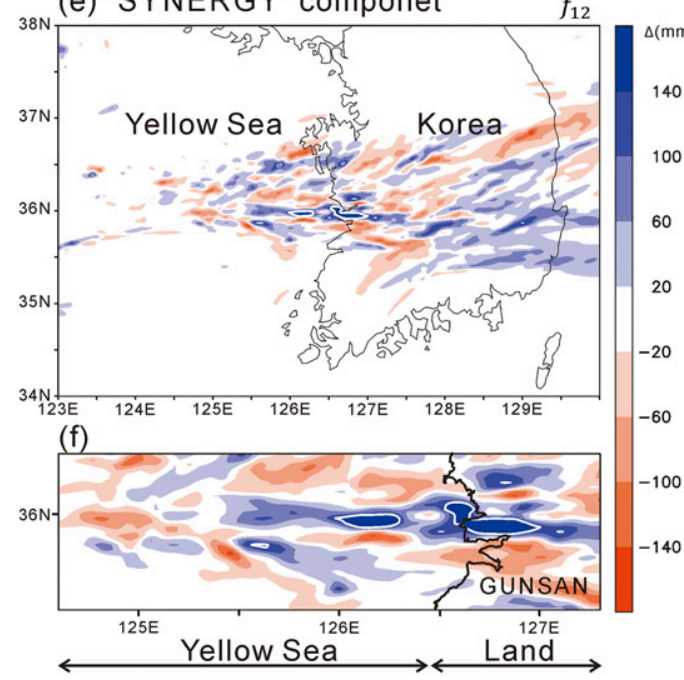

between the local warm SST and topography increased the rainfall in the offshore Gunsan area. Therefore, the local warm SST impacts the continuous development of MCSs over the Yellow Sea, and the terrain has a role in the enhancement of MCSs in the Gunsan area, Korea.

This case study offers new insights into the cause of heavy-rainfall-producing linear MCSs over the Yellow Sea during the summer season. Further statistical analysis using long-term data of events is needed to fully understand the mechanism of their formation and development processes.

Acknowledgments. This research was supported by the Korea Meteorological Institute under Grant KMI 2021-03413. Jong-Hoon Jeong was supported by the U.S. Department of Energy Atmospheric System Research (ASR) under Contract DESC0020332. The authors thank Dr. Cheol-Hwan You, Dr. Mi-Young Kang, and Dr. Sang-Min. Jang at Pukyong National University and Dr. In-Seong Han at National Institute of

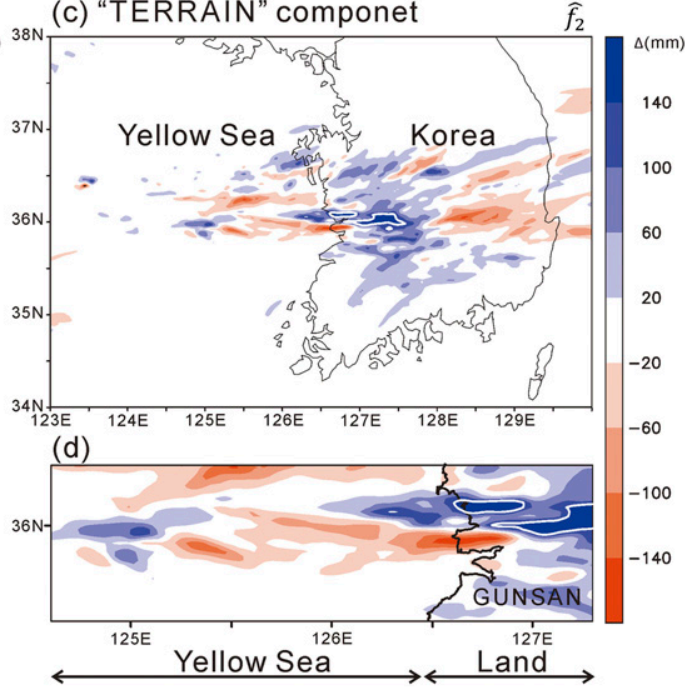

FIG. 17. Components of the factor separation analysis related to accumulated rainfall from 0000 to 1200 LST 13 Aug 2012: (a) "SST" component, (b) "TERRAIN" component, and (c) "SYNERGY" component. The white lines indicate areas where the difference in rainfall is more than $140 \mathrm{~mm}$. The dotted box in (a) indicates the domain for (b), (d), and (f) (see Table 3).
Fisheries Science in Korea, for their fruitful advice. We also thank Dr. Kazuhisa Tsuboki, Nagoya University, Japan for his fruitful discussion.

Data availability statement. The Doppler radar and surface observation data used in this study are available from the KMA (http://data.kma.go.kr/). TRMM 3B42 data can be downloaded from the website: https://disc.gsfc.nasa.gov/. NCEP reanalysis data were obtained from the NOAA/OAR/ESRL PSD, Boulder, Colorado, from their website at http:// www.esrl.noaa.gov/psd. The Himawari-8 satellite images were obtained from Weather Home, Kochi University (http://weather.is.kochi-u.ac.jp/). MGDSSTs were obtained from the NEAR-GOOS regional real-time database (http:// ds.data.jma.go.jp). The outputs of the CReSS simulation were reproduced using CReSS (http://www.rain.hyarc.nagoyau.ac.jp/ tsuboki/cress_html/index_cress_jpn.html). The ERA5 reanalysis data were available from the Climate Date Store (CDS https://cds.climate.copernicus.eu). 


\section{REFERENCES}

Alpert, P., and T. Sholokhman, 2011: Factor Separation in the Atmosphere: Applications and Future Prospects. Cambridge University Press, 292 pp.

Asselin, R., 1972: Frequency filter for time integrations. Mon. Wea. Rev., 100, 487-490, https://doi.org/10.1175/1520-0493(1972) $100<0487$ :FFFTI $>2.3$.CO;2.

Bluestein, H. B., and M. H. Jain, 1985: Formation of mesoscale lines of precipitation: Severe squall lines in Oklahoma during the spring. J. Atmos. Sci., 42, 1711-1732, https://doi.org/ 10.1175/1520-0469(1985)042<1711:FOMLOP>2.0.CO;2.

Chelton, D. B., and S.-P. Xie, 2010: Coupled ocean-atmosphere interaction at the oceanic mesoscale. Oceanography, 23, 5269, https://doi.org/10.5670/oceanog.2010.05.

—, M. G. Schlax, M. H. Freilich, and R. F. Milliff, 2004: Satellite measurements reveal persistent small-scale features in ocean winds. Science, 303, 978-983, https://doi.org/10.1126/ science.1091901.

Cotton, W. R., G. J. Tripoli, R. M. Rauber, and E. A. Mulvihill, 1986: Numerical simulation of the effects of varying ice crystal nucleation rates and aggregation processes on orographic snowfall. J. Climate Appl. Meteor., 25, 1658-1680, https://doi.org/10.1175/1520-0450(1986)025<1658:NSOTEO> 2.0.CO;2.

Cressman, G. P., 1959: An operational objective analysis system. Mon. Wea. Rev., 87, 367-374, https://doi.org/10.1175/15200493(1959)087<0367:AOOAS>2.0.CO;2.

Daly, C., 2006: Guidelines for assessing the suitability of spatial climate data sets. Int. J. Climatol., 26, 707-721, https://doi.org/ 10.1002/joc.1322.

—, M. Halbleib, J. I. Smith, W. P. Gibson, M. K. Doggett, G. H. Taylor, J. Curtis, and P. P. Pasteris, 2008: Physiographically sensitive mapping of climatological temperature and precipitation across the conterminous United States. Int. J. Climatol., 28, 2031-2064, https://doi.org/10.1002/joc.1688.

Ding, Y., 2004: Seasonal march of the East Asian summer monsoon. The East Asian Monsoon, C.-P. Chang, Ed., World Scientific, 3-5, https://doi.org/10.1142/9789812701411_0001.

Doswell, C. A., H. E. Brooks, and R. A. Maddox, 1996: Flash flood forecasting: An ingredients-based methodology. Wea. Forecasting, 11, 560-581, https://doi.org/10.1175/1520-0434(1996)011<0560: FFFAIB $>2.0 . \mathrm{CO} ; 2$.

Du, Y., and G. Chen, 2018: Heavy rainfall associated with double low-level jets over southern China. Part I: Ensemble-based analysis. Mon. Wea. Rev., 146, 3827-3844, https://doi.org/10.1175/ MWR-D-18-0101.1.

— level jets over southern China. Part II: Convection initiation. Mon. Wea. Rev., 147, 543-565, https://doi.org/10.1175/MWRD-18-0102.1.

$\longrightarrow$, and — 2019b: Climatology of low-level jets and their impact on rainfall over southern China during early-summer rainy season. J. Climate, 32, 8813-8833, https://doi.org/10.1175/ JCLI-D-19-0306.1.

—_, - - B. Han, L. Bai, and M. Li, 2020: Convection initiation and growth at the coast of South China. Part II: Effects of the terrain, coastline, and cold pools. Mon. Wea. Rev., 148, 3871-3892, https://doi.org/10.1175/MWR-D-200090.1 .

Fritsch, J. M., and R. Carbone, 2004: Improving quantitative precipitation forecasts in the warm season: A USWRP research and development strategy. Bull. Amer. Meteor. Soc., 85, 955966, https://doi.org/10.1175/BAMS-85-7-955.
Ha, K.-J., and S.-S. Lee, 2007: On the interannual variability of the Bonin high associated with the East Asian summer monsoon rain. Climate Dyn., 28, 67-83, https://doi.org/10.1007/s00382006-0169-x.

Herman, G. R., and R. S. Schumacher, 2018: Flash flood verification: Pondering precipitation proxies. J. Hydrometeor., 19, 1753-1776, https://doi.org/10.1175/JHM-D-18-0092.1.

Hersbach, H., and Coauthors, 2020: The ERA5 global reanalysis. Quart. J. Roy. Meteor. Soc., 146, 1999-2049, https://doi.org/ 10.1002/qj.3803.

Hewitson, B. C., and R. G. Crane, 2005: Gridded area-averaged daily precipitation via conditional interpolation. J. Climate, $\mathbf{1 8}$, 41-57, https://doi.org/10.1175/JCLI3246.1.

Hosoda, K., and F. Sakaida, 2016: Global daily high-resolution satellite-based foundation sea surface temperature dataset: Development and validation against two definitions of foundation SST. Remote Sens., 8, 962, https://doi.org/10.3390/ rs8110962.

Houze, R. A., Jr., 2004: Mesoscale convective systems. Rev. Geophys., 42, RG4003, https://doi.org/10.1029/2004RG000150.

_ 2019: 100 years of research on mesoscale convective systems. A Century of Progress in Atmospheric and Related Sciences: Celebrating the American Meteorological Society Centennial, Meteor. Monogr., No. 59, 17.1-17.54, https://doi.org/10.1175/ AMSMONOGRAPHS-D-18-0001.1.

Huffman, G. J., and Coauthors, 2007: The TRMM Multisatellite Precipitation Analysis (TMPA): Quasi-global, multiyear, combined-sensor precipitation estimates at fine scales. J. Hydrometeor., 8, 38-55, https://doi.org/10.1175/JHM560.1.

Ikawa, M., and K. Saito, 1991: Description of a nonhydrostatic model developed at the Forecast Research Department of the MRI. MRI Tech. Rep. 28, 238 pp.

Jang, S.-M., D.-I. Lee, J.-H. Jeong, S.-H. Park, S. Shimizu, H. Uyeda, and Y.-S. Suh, 2014: Radar reflectivity and wind fields analysis by using two X-band Doppler radars at Okinawa, Japan from 11 to 12 June 2007. Meteor. Appl., 21, 898-909, https://doi.org/10.1002/met.1427.

Jankov, I., W. A. Gallus, M. Segal, B. Shaw, and S. E. Koch, 2005: The impact of different WRF Model physical parameterizations and their interactions on warm season MCS rainfall. Wea. Forecasting, 20, 1048-1060, https://doi.org/10.1175/ WAF888.1.

Jeong, H.-G., J.-B. Ahn, J. Lee, K.-M. Shim, and M.-P. Jung, 2020: Improvement of daily precipitation estimations using PRISM with inverse-distance weighting. Theor. Appl. Climatol., 139, 923-934, https://doi.org/10.1007/s00704-019-03012-6.

Jeong, J.-H., D.-I. Lee, C.-C. Wang, S.-M. Jang, S.-H. Park, and S.-A. Jung, 2014: Structure and evolution of line-shaped convective systems associated with Changma front during GRL PHONE-09: 6 July 2009 case. Meteor. Appl., 21, 786-794, https://doi.org/10.1002/met.1418.

,-- , and — - 2016a: Impact of the cold pool on mesoscale convective system-produced extreme rainfall over southeastern South Korea: 7 July 2009. Mon. Wea. Rev., 144, 39854006, https://doi.org/10.1175/MWR-D-16-0131.1.

,,--- , and I.-S. Han, 2016b: Characteristics of mesoscaleconvective-system-produced extreme rainfall over southeastern South Korea: 7 July 2009. Nat. Hazards Earth Syst. Sci., 16, 927-939, https://doi.org/10.5194/nhess-16-927-2016.

Jeong, J. I., and R. Park, 2013: A study of the effects of SST deviations on heavy snowfall over the Yellow Sea (in Korea). Atmosphere, 23, 161-169, https://doi.org/10.14191/ Atmos.2013.23.2.161. 
_ R. J. Park, and Y.-K. Cho, 2014: Effect of sea surface temperature errors on snowfall in WRF: A case study of a heavy snowfall event in Korea in December 2012. Terr. Atmos. Oceanic Sci., 25, 827, https://doi.org/10.3319/TAO.2014.08.15.01(A).

Jiang, X., Y. Luo, D.-L. Zhang, and M. Wu, 2020: Urbanization enhanced summertime extreme hourly precipitation over the Yangtze River Delta. J. Climate, 33, 5809-5826, https://doi.org/ 10.1175/JCLI-D-19-0884.1.

Kalnay, E., and Coauthors, 1996: The NCEP/NCAR 40-Year Reanalysis Project. Bull. Amer. Meteor. Soc., 77, 437-471, https://doi.org/10.1175/1520-0477(1996)077<0437:TNYRP> 2.0.CO;2.

Kanada, S., H. Aiki, K. Tsuboki, and I. Takayabu, 2021: Future changes of a slow-moving intense typhoon with global warming: A case study using a regional 1-km-mesh atmosphere-ocean coupled model. SOLA, 17A, 14-20, https://doi.org/10.2151/sola.17A-003.

Kato, T., 2020: Quasi-stationary band-shaped precipitation systems, named "senjo-kousuitai", causing localized heavy rainfall in Japan. J. Meteor. Soc. Japan, 98, 485-509, https://doi.org/ 10.2151/jmsj.2020-029.

Ke, C.-Y., K.-S. Chung, T.-C. Chen Wang, and Y.-C. Liou, 2019: Analysis of heavy rainfall and barrier-jet evolution during Mei-Yu season using multiple Doppler radar retrievals: A case study on 11 June 2012. Tellus, 71A, 1571369, https://doi.org/ 10.1080/16000870.2019.1571369.

Kim, T., S.-H. Choo, J.-H. Moon, and P.-H. Chang, 2017: Contribution of tropical cyclones to abnormal sea surface temperature warming in the Yellow Sea in December 2004. Dyn. Atmos. Oceans, 80, 97-109, https://doi.org/10.1016/j.dynatmoce.2017.10.002.

Klemp, J. B., and R. B. Wilhelmson, 1978: The simulation of threedimensional convective storm dynamics. J. Atmos. Sci., 35, 1070-1096, https://doi.org/10.1175/1520-0469(1978)035<1070: TSOTDC $>2.0 . \mathrm{CO} ; 2$.

Kondo, J., 1976: Heat balance of the China Sea during the air mass transformation experiment. J. Meteor. Soc. Japan, 54, 382-398, https://doi.org/10.2151/jmsj1965.54.6_382.

Kurihara, Y., T. Sakurai, and T. Kuragano, 2006: Global daily sea surface temperature analysis using data from satellite microwave radiometer, satellite infrared radiometer and in-situ observations (in Japanese). Wea. Service Bull., 73, S1-S18.

Lee, K. O., H. Uyeda, S. Shimizu, and D. I. Lee, 2012: DualDoppler radar analysis of the enhancement of a precipitation system on the northern side of Mt. Halla, Jeju Island, Korea on 6 July 2007. Atmos. Res., 118, 133-152, https://doi.org/10.1016/ j.atmosres.2012.06.017.

Lee, J.-T., D.-I. Lee, C.-H. You, H. Uyeda, Y.-C. Liou, and I.-S. Han, 2014: Dual-Doppler radar analysis of a near-shore line-shaped convective system on 27 July 2011, Korea: A case study. Tellus, 66A, 23453, https://doi.org/10.3402/tellusa.v66.23453.

,-- , S. Shimizu, and C.-H. You, 2019: Analysis of determinants for an enhanced and long-lasting coastal convective system by means of a case study (26 July 2011). Adv. Atmos. Sci., 36, 1327-1339, https://doi.org/10.1007/s00376-019-9025-x.

Li, M., Y. Luo, D.-L. Zhang, M. Chen, C. Wu, J. Yin, and R. Ma, 2020: Analysis of a record-breaking rainfall event associated with a monsoon coastal megacity of South China using multisource data. IEEE Trans. Geosci. Remote Sens., https:// doi.org/10.1109/TGRS.2020.3029831, in press.

Li, X., Y. Luo, and Z. Guan, 2014: The persistent heavy rainfall over Southern China in June 2010: Evolution of synoptic systems and the effects of the Tibetan Plateau heating. J. Meteor. Res., 28, 540-560, https://doi.org/10.1007/s13351014-3284-3.
Li, Y., and R. E. Carbone, 2012: Excitation of rainfall over the tropical western Pacific. J. Atmos. Sci., 69, 2983-2994, https:// doi.org/10.1175/JAS-D-11-0245.1.

Li, Z., Y. Luo, Y. Du, and J. C. L. Chan, 2020: Statistical characteristics of pre-summer rainfall over South China and associated synoptic conditions. J. Meteor. Soc. Japan, 98, 213-233, https://doi.org/10.2151/jmsj.2020-012.

Lin, Y.-L., R. D. Farley, and H. D. Orville, 1983: Bulk parameterization of the snow field in a cloud model. J. Climate Appl. Meteor., 22, 1065-1092, https://doi.org/10.1175/1520-0450(1983) 022<1065:BPOTSF $>2.0 . C O ; 2$.

Lin, Y., J. Fan, J.-H. Jeong, Y. Zhang, C. R. Homeyer, and J. Wang, 2021: Urbanization-induced land and aerosol impacts on storm propagation and hail characteristics. J. Atmos. Sci., 78, 925-947, https://doi.org/10.1175/JAS-D-20-0106.1.

Liu, X., Y. Luo, Z. Guan, and D.-L. Zhang, 2018: An extreme rainfall event in coastal South China during SCMREX-2014: Formation and roles of rainband and echo trainings. J. Geophys. Res. Atmos., 123, 9256-9278, https://doi.org/10.1029/2018JD028418.

,-- L. Huang, D.-L. Zhang, and Z. Guan, 2020: Roles of double low-level jets in the generation of coexisting inland and coastal heavy rainfall over south China during the presummer rainy season. J. Geophys. Res. Atmos., 125, e2020JD032890, https://doi.org/10.1029/2020JD032890.

Louis, J., M. Tiedtke, and J. Geleyn, 1982: A short history of the PBL parameterization at ECMWF. Workshop on Planetary Boundary Layer Parameterization, Reading, United Kingdom, ECMWF, 59-80.

Luo, Y., and Y. Chen, 2015: Investigation of the predictability and physical mechanisms of an extreme-rainfall-producing mesoscale convective system along the Meiyu front in East China: An ensemble approach. J. Geophys. Res. Atmos., 120, $10593-$ 10 618, https://doi.org/10.1002/2015JD023584.

, Y. Gong, and D.-L. Zhang, 2014: Initiation and organizational modes of an extreme-rain-producing mesoscale convective system along a mei-yu front in East China. Mon. Wea. Rev., 142, 203-221, https://doi.org/10.1175/MWR-D-13-00111.1.

—, M. Wu, F. Ren, J. Li, and W.-K. Wong, 2016: Synoptic situations of extreme hourly precipitation over China. J. Climate, 29, 8703-8719, https://doi.org/10.1175/JCLI-D-16-0057.1.

Meng, W., J. Li, A. Wang, and R. Q. Feng, 2005: Effects of condensation heating and surface fluxes on the development of a South China mesoscale convective system (MCS). J. Trop. Meteor., 11, 144-152.

Min, K.-S, K. Tsuboki, K. Yoshioka, Y. Moroda, and S. Kanada, 2021: Formation mechanism of a stationary line-shaped precipitation system in the Kinki District, Japan-Case study on 1 September 2015 event. J. Meteor. Soc. Japan, in press.

Minobe, S., A. Kuwano-Yoshida, N. Komori, S.-P. Xie, and R. J. Small, 2008: Influence of the Gulf Stream on the troposphere. Nature, 452, 206-209, https://doi.org/10.1038/nature06690.

Miyama, T., M. Nonaka, H. Nakamura, and A. Kuwano-Yoshida, 2012: A striking early-summer event of a convective rainband persistent along the warm Kuroshio in the East China Sea. Tellus, 64, 18962, https://doi.org/10.3402/tellusa.v64i0.18962.

Moroda, Y., K. Tsuboki, S. Satoh, K. Nakagawa, T. Ushio, and S. Shimizu, 2021: Structure and evolution of precipitation cores in an isolated convective storm observed by phased array weather radar. J. Meteor. Soc. JapanI, 99, 765-784, https://doi.org/10.2151/jmsj.2021-038.

Moteki, Q., and A. Manda, 2013: Seasonal migration of the Baiu Frontal Zone over the East China Sea: Sea surface temperature effect. SOLA, 9, 19-22, https://doi.org/10.2151/sola.2013-005. 
Murakami, M., 1990: Numerical modeling of dynamical and microphysical evolution of an isolated convective cloud. J. Meteor. Soc. Japan, 68, 107-128.

_ , T. L. Clark, and W. D. Hall, 1994: Numerical simulations of convective snow clouds over the Sea of Japan. J. Meteor. Soc. Japan, 72, 43-62.

Orlanski, I., 1975: A rational subdivision of scales for atmospheric processes. Bull. Amer. Meteor. Soc., 56, 527-530.

Park, R. S., Y.-K. Cho, B.-J. Choi, and C. H. Song, 2011: Implications of sea surface temperature deviations in the prediction of wind and precipitable water over the Yellow Sea. J. Geophys. Res., 116, D17106, https://doi.org/10.1029/2011JD016191.

Parker, M. D., and R. H. Johnson, 2000: The operational JMA nonhydrostatic mesoscale model. Mon. Wea. Rev., 128, 3413-3436, https://doi.org/10.1175/1520-0493(2001)129<3413: OMOMMC $>2.0 . \mathrm{CO} ; 2$.

Romero, R., C. A. Doswell, and C. Ramis, 2000: Mesoscale numerical study of two cases of long-lived quasi-stationary convective systems over eastern Spain. Mon. Wea. Rev., 128, 3731-3751, https://doi.org/ 10.1175/1520-0493(2001)129<3731:MNSOTC >2.0.CO;2.

Saito, K., and Coauthors, 2006: The operational JMA nonhydrostatic mesoscale model. Mon. Wea. Rev., 134, 1266-1298, https://doi.org/10.1175/MWR3120.1.

Sakurai, T., Y. Kurihara, and T. Kuragano, 2005: Merged satellite and in-situ data global daily SST. Proc. 2005 IEEE Int. Conf. on Geoscience Remote Sensing. Symp. (IGARSS'05), Seoul, South Korea, IEEE, 2606-2608.

Sasaki, Y. N., S. Minobe, T. Asai, and M. Inatsu, 2012: Influence of the Kuroshio in the East China Sea on the early summer (baiu) rain. J. Climate, 25, 6627-6645, https://doi.org/10.1175/JCLI-D-11-00727.1.

Sato, K., and Coauthors, 2016: Influence of the Kuroshio on mesoscale convective systems in the baiu frontal zone over the East China Sea. Mon. Wea. Rev., 144, 1017-1033, https:// doi.org/10.1175/MWR-D-15-0139.1.

Schumacher, R. S., 2017: Heavy rainfall and flash flooding. Nat. Hazard Sci., https://doi.org/10.1093/acrefore/9780199389407.013.132.

—_, and R. H. Johnson, 2005: Organization and environmental properties of extreme-rain-producing mesoscale convective systems. Mon. Wea. Rev., 133, 961-976, https://doi.org/10.1175/MWR2899.1.

— during 1999-2003. Wea. Forecasting, 21, 69-85, https://doi.org/ 10.1175/WAF900.1.

Seo, K.-H., J.-H. Son, and J.-Y. Lee, 2011: A new look at Changma (in Korea). Atmosphere, 21, 109-121.

Shimizu, S., K. Iwanami, R. Kato, N. Sakurai, T. Maesaka, K. Kieda, Y. Shusse, and S. Suzuki, 2019: Assimilation impact of high-temporal-resolution volume scans on quantitative precipitation forecasts in a severe storm: Evidence from nudging data assimilation experiments with a thermodynamic retrieval method. Quart. J. Roy. Meteor. Soc., 145, 2139-2160, https://doi.org/https://doi.org/10.1002/qj.3548.

Small, R. J., 2008: Air-sea interaction over ocean fronts and eddies. Dyn. Atmos. Oceans, 45, 274-319, https://doi.org/10.1016/ j.dynatmoce.2008.01.001.

Smith, T. L., S. G. Benjamin, S. I. Gutman, and S. Sahm, 2007: Short-range forecast impact from assimilation of GPS-IPW observations into the Rapid Update Cycle. Mon. Wea. Rev., 135, 2914-2930, https://doi.org/10.1175/MWR3436.1.

Stein, U., and P. Alpert, 1993: Factor separation in numerical simulations. J. Atmos. Sci., 50, 2107-2115, https://doi.org/ 10.1175/1520-0469(1993)050<2107:FSINS $>2.0$. CO 2 .

Sukovich, E. M., F. M. Ralph, F. E. Barthold, D. W. Reynolds, and D. R. Novak, 2014: Extreme quantitative precipitation forecast performance at the Weather Prediction Center from 2001 to 2011. Wea. Forecasting, 29, 894-911, https://doi.org/ 10.1175/WAF-D-13-00061.1.

Tai, S.-L., Y.-C. Liou, S.-F. Chang, and J. Sun, 2020: The heavy rainfall mechanism revealed by a terrain-resolving 4DVar data assimilation system-A case study. Mon. Wea. Rev., 148, 2307-2330, https://doi.org/10.1175/MWR-D-19-0244.1.

Toy, M. D., and R. H. Johnson, 2014: The influence of an SST front on a heavy rainfall event over coastal Taiwan during TiMREX. J. Atmos. Sci., 71, 3223-3249, https://doi.org/10.1175/JAS-D-13-0338.1.

Tsuboki, K., and A. Sakakibara, 2002: Large-scale parallel computing of cloud resolving storm simulator. High Performance Computing, H. P. Zima et al., Eds., Springer, 243-259, https:// doi.org/10.1007/3-540-47847-7_21.

—_, and _ 2007: Numerical Prediction of High-Impact Weather Systems: The Textbook for Seventeenth IHP Training Course 2007. HyARC, Nagoya University, and UNESCO, 273 pp.

— rainfalls in association with monsoon systems and typhoons using cloud-resolving models. The Multiscale Global Monsoon System, C.-P. Chang et al., Eds., World Scientific, 113-131.

Tsuguti, H., and T. Kato, 2014: Contributing factors of the heavy rainfall event at Amami-Oshima island, Japan, on 20 October 2010. J. Meteor. Soc. Japan, 92, 163-183.

Uccellini, L. W., and D. R. Johnson, 1979: The coupling of upper and lower tropospheric jet streaks and implications for the development of severe convective storms. Mon. Wea. Rev., 107, 682-703, https://doi.org/10.1175/1520-0493(1979)107<0682: TCOUAL $>2.0 . \mathrm{CO} ; 2$.

Wang, C.-C., G. T.-J. Chen, T.-C. Chen, and K. Tsuboki, 2005: A numerical study on the effects of Taiwan topography on a convective line during the mei-yu season. Mon. Wea. Rev., 133, 3217-3242, https://doi.org/10.1175/MWR3028.1.

— B.-K. Chiou, G. T.-J. Chen, H.-C. Kuo, and C.-H. Liu, 2016: A numerical study of back-building process in a quasistationary rainband with extreme rainfall over northern Taiwan during 11-12 June 2012. Atmos. Chem. Phys., 16, 12359 12 382, https://doi.org/10.5194/acp-16-12359-2016.

— , F.-C. Chien, S. Paul, D.-I. Lee, and P.-Y. Chuang, 2017: An evaluation of WRF rainfall forecasts in Taiwan during three mei-yu seasons from 2008 to 2010. Wea. Forecasting, 32, 13291351, https://doi.org/10.1175/WAF-D-16-0190.1.

Wu, M., C.-C. Wu, T.-H. Yen, and Y. Luo, 2017: Synoptic analysis of extreme hourly precipitation in Taiwan during 2003-12. Mon. Wea. Rev., 145, 5123-5140, https://doi.org/10.1175/ MWR-D-17-0230.1.

Xia, R., and D.-L. Zhang, 2019: An observational analysis of three extreme rainfall episodes of 19-20 July 2016 along the Taihang mountains in north China. Mon. Wea. Rev., 147, 4199-4220, https://doi.org/10.1175/MWR-D-18-0402.1.

Xie, S.-P., 2004: Satellite observations of cool ocean-atmosphere interaction. Bull. Amer. Meteor. Soc., 85, 195-208, https:// doi.org/10.1175/BAMS-85-2-195.

Xu, H., M. Xu, S.-P. Xie, and Y. Wang, 2011: Deep atmospheric response to the spring Kuroshio over the East China Sea. J. Climate, 24, 4959-4972, https://doi.org/10.1175/JCLI-D-10-05034.1.

Yin, J., D.-L. Zhang, Y. Luo, and R. Ma, 2020: On the extreme rainfall event of 7 May 2017 over the coastal city of Guangzhou. Part I: Impacts of urbanization and orography. Mon. Wea. Rev., 148, 955-979, https://doi.org/10.1175/MWR-D-19-0212.1.

Yu, C.-K., and Y. Chen, 2011: Surface fluctuations associated with tropical cyclone rainbands observed near Taiwan during 2000-08. J. Atmos. Sci., 68, 1568-1585, https://oi.org/10.1175/2011JAS3725.1. 